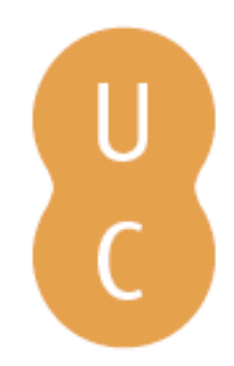

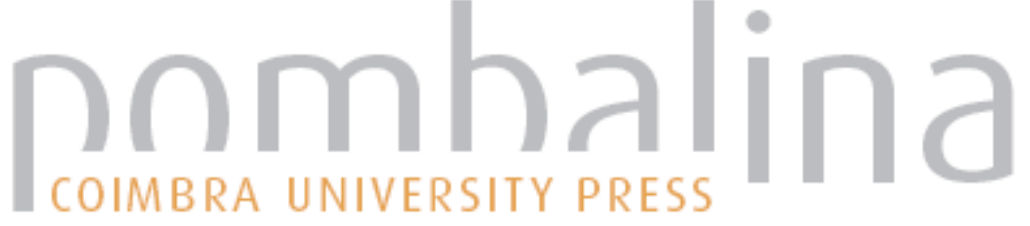

\section{História apostólica: a gesta de S. Paulo}
Autor(es):
Arátor
Publicado por: Imprensa da Universidade de Coimbra
URL persistente:
URl:http://hdl.handle.net/10316.2/2401
DOI:
DOI:http://dx.doi.org/10.14195/978-989-26-0781-8

Accessed : $\quad$ 26-Apr-2023 12:19:54

A navegação consulta e descarregamento dos títulos inseridos nas Bibliotecas Digitais UC Digitalis, UC Pombalina e UC Impactum, pressupõem a aceitação plena e sem reservas dos Termos e Condições de Uso destas Bibliotecas Digitais, disponíveis em https://digitalis.uc.pt/pt-pt/termos.

Conforme exposto nos referidos Termos e Condições de Uso, o descarregamento de títulos de acesso restrito requer uma licença válida de autorização devendo o utilizador aceder ao(s) documento(s) a partir de um endereço de IP da instituição detentora da supramencionada licença.

Ao utilizador é apenas permitido o descarregamento para uso pessoal, pelo que o emprego do(s) título(s) descarregado(s) para outro fim, designadamente comercial, carece de autorização do respetivo autor ou editor da obra.

Na medida em que todas as obras da UC Digitalis se encontram protegidas pelo Código do Direito de Autor e Direitos Conexos e demais legislação aplicável, toda a cópia, parcial ou total, deste documento, nos casos em que é legalmente admitida, deverá conter ou fazer-se acompanhar por este aviso.

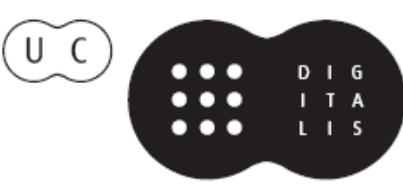


Colecção Autores Gregos e Latinos

Série TeXtos

\section{Arátor}

\section{História Apostólica a Gesta de S. Paulo}

TRADUÇÃO DO LATIM, INTRODUÇÃO E NOTAS José Henrique Manso 
(Página deixada propositadamente em branco) 


\section{Arátor}

\section{História Apostólica \\ A gesta de S. Paulo}

TraduÇão do LaTim, INTROdUÇÃo E NOTAS DE José Henrique Manso

Universidade da Beira Interior

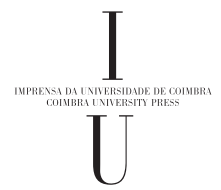


Todos os Volumes desta SÉRIE SÃo SUJeITOS A ARbitragem CIENTÍFICA INDEPENDENTE.

Título - História Apostólica - A Gesta de S. Paulo

Tradução do latim, introdução e notas: José Henrique Manso AUtor • ArÁtor

Série Autores Gregos e Latinos - Textos

Coordenador Científico do plano de ediçáo: Maria do Céu Fialho

\section{Conselho Editorial}

José Ribeiro Ferreira

Francisco de Oliveira

Maria de Fátima Silva

Nair Castro Soares

Director Técnico: Delfim Leão

Obra realizada no Âmbito das actividades da UI\&D

Centro de Estudos Clássicos e Humanísticos

\section{EdiçÃo}

Imprensa da Universidade de Coimbra

URL: http://www.uc.pt/imprensa_uc

E-mail: imprensauc@ci.uc.pt

Vendas online:

http://livrariadaimprensa.uc.pt

\section{COORDENAÇÃo EDITORIAL}

Imprensa da Universidade de Coimbra

Concepçẫo gráfica \& PAginaÇão

Rodolfo Lopes \& Nelson Henrique

Pré-IMPREssão

Imprensa da Universidade de Coimbra

\section{Impressão e ACABAmento}

Simốes \& Linhares

ISBN

978-989-26-0517-3

ISBN DigITAL

978-989-26-0781-8

\section{DOI}

http://dx.doi.org/

10.14195/978-989-26-0781-8

\section{Depósito Legal}

$358458 / 13$

1a EDIÇĂO: CECH • 2010

2a Ediçấo: IUC • 2012

3a EdiçÁo: IUC • 2013

(C) Abril 2013.

Imprensa da Universidade de CoImbra

Classica Digitalia Vniversitatis Conimbrigensis (http://classicadigitalia.uc.pt) Centro de Estudos Clássicos e Humanísticos da Universidade de Coimbra

Reservados todos os direitos. Nos termos legais fica expressamente proibida a reproduçáo total ou parcial por qualquer meio, em papel ou em edição electrónica, sem autorizaçâo expressa dos titulares dos direitos. É desde já excepcionada a utilização em circuitos académicos fechados para apoio a leccionação ou extensâo cultural por via de e-learning. 


\section{ÍNDICE}

\section{INTRODUÇÃO}

ReCePÇÃo de Arátor 9

ARÁtor: DE FUnCIONÁRIO DA CORTE A HOMEM DA Igreja 16

Os feitos de S. Paulo na História apostólica 25

História apostólica - A GeSTA de S. PAULO

EPISTOLA DO SUBDIÁCONO ARÁTOR A FLORIANO 41

EPÍSTOLA A VIGILIO

HISTÓRIA APOSTÓLICA, LIVRO SEGUNDO 49

EPISTOLA de ARÁtor a PARTÉNIO 111

$\begin{array}{ll}\text { Bibliografia } & 119\end{array}$

ÍNDICE ONOMÁSTICO 
(Página deixada propositadamente em branco) 
Para as minhas filhas, Clara Sofia e Helena Isabel 
(Página deixada propositadamente em branco) 


\section{INTRODUÇÃO}

\section{ReCEPÇÃo de ARÁtor}

É facto reconhecido pela generalidade dos estudiosos que o tratamento dado pela modernidade a esse grande autor medieval que foi Arátor fica muito aquém dos seus reais méritos. Na verdade, os dicionários, enciclopédias e Histórias da Igreja não têm dedicado ao autor e à sua obra mais do que algumas escassas linhas, frequentemente imprecisas e com juízos valorativos nada favoráveis ${ }^{1}$. Não obstante, alguns trabalhos importantes têm vindo a inverter esta tendência, que chegou ao ponto de epitetar a História apostólica como "o pior dos poemas sobre um assunto excelente" 2 .

${ }^{1}$ A propósito da escassez de informaçōes biobibliográficas remetemos para as oito linhas que a Encyclopaedia Britannica (vol. 2, 1962 216) dedica a Arátor. Quanto a informaçôes incorrectas, citamos o artigo de P. de Labriolle no Dictionnaire d'histoire et de géographie écclesiastiques (vol. 3, 1924 col. 1443-1445), quando afirma que Arátor recitou o seu extenso poema durante quatro dias consecutivos $(13,14,15$, e 16 de Abril de 544), sendo certo que os manuscritos são claros quanto às datas em que ocorreu tal récita: 13 e 17 de Abril, e 8 e 30 Maio de 544. Finalmente, a menorização do poeta pode ler-se em Louis Duchesne, que, na famosa L'Église au VI' siècle (1925 155), afirma: "Arator [...] mit en hexamètres les Actes des Apôtres, et ce jeu d'esprit fut l'object d'une lecture solennelle, en 544". Tais palavras săo objecto de viva contestação por parte de François Châtillon, que, partindo desta frase do historiador e esmiuçando a presença do nome Arátor em obras de referência, conclui: "Procès-verbal de carence, d'insuffisance, d'ignorance, d'erreur, de légèreté, parfois aussi d'insincérité" (1963 11).

${ }^{2}$ Vd. Duckett 1961 70, tradução nossa. 
A publicação do poema no Corpus Scriptorum Ecclesiasticorum Latinorum (CSEL), em 1951, sob a responsabilidade de Arthur Patch McKinlay, com o título Aratoris subdiaconi De Actibus apostolorum, bem como os estudos deste norte-americano, nomeadamente a propósito dos manuscritos medievais, constituíram ponto de viragem. Nas páginas iniciais, McKinlay inclui uma rubrica intitulada De arte et uita Aratoris testimonia, onde podemos ver a extraordinária divulgação do poema aratoriano e inferir da admiração que numerosos autores dos mais diversos quadrantes nutriram por Arátor ${ }^{3}$. Um dos mais antigos, Beda (século VIII), ao debruçar-se sobre o mesmo tema - os feitos apostólicos -, reconhece Arátor como grande autoridade na matéria, que ele terá seguido de perto:

In quo me opusculo, cum alii plurimi fidei catholicae scriptores, tum maxime iunauit Arator, sanctae Romanae ecclesiae subdiaconus, qui ipsum ex ordine librum heroico carmine percurrens nonnulos in eodem metro allegoriae flores admiscuit ${ }^{4}$.

Mas muitos outros citam, imitam ou admiram a obra épica de Arátor. Para referirmos alguns dos mais conhecidos, e ainda de acordo com a extensa lista de testemunhos coligidos por McKinlay, anotemos que Venâncio Fortunato (530-600), Adelmo (639-709), Alcuíno (735-804) ou Rábano Mauro (776-859) se contam entre aqueles que, de uma forma ou de outra,

${ }^{3}$ Vd. McKinlay 1951 XXI-LIX.

${ }^{4}$ Vd. Beda, Expositio Actuum apostolorum, prologus. 
se referem à História apostólica de Arátor. A propósito do primeiro testemunho, é de salientar que Venâncio Fortunato escreveu a sua obra poucos anos após o aparecimento da História apostólica, tendo imitado o antecessor no vocabulário, nas imagens e na textura dos versos, como constata Deproost ${ }^{5}$, referindo-se às lacunas dos testemunhos aduzidos por McKinlay, no capítulo supracitado. Ainda a este propósito, Sven Blomgren aponta quarenta e seis passos da obra do bispo de Poitiers inspirados na História apostólica, muito concretamente no ponto 2 do seu artigo Ad Aratorem et Fortunatum adnotationes, cujo subtítulo não podia ser mais explícito: De Venantio Fortunato Aratoris imitatore ${ }^{6}$.

E não se coíbem alguns autores de comparar o poema de Arátor à epopeia virgiliana, como um certo Joâo de Fulda, que considera a História apostólica superior à Eneida, afirmando a vanidade da segunda face à utilidade da primeira:

Virgilius paleas, frumentum probet Arator. I Hic mansura docet, ille caduca refert?

Arátor foi presença relevante no ensino medieval, formando com Juvenco, Prudêncio e Sedúlio a "nova

${ }^{5}$ Cf. Deproost 1990 37: “[...] citons, par exemple, l'expression Iudaea ferox, que l'on trouve en ARAT., II, 659 et VEN. FORT., Carm. I, 3, 7. Mais une étude comparative des deux poètes révélerait bien d'autres traits communs dans le vocabulaire, les images, les tournures de phrase et même les alliances des mots".

${ }^{6} \mathrm{Vd}$. Blomgren 1974 143-155.

${ }^{7}$ Versus Iohannes Foldensis Didascali (PLACI 392), v. 13-14. Vd. McKinlay 1951 XXIX. 
quadriga das epopeias bíblicas" (em contraponto com a "quadriga escolar", constituída por Virgílio, Salústio, Terêncio e Cícero), segundo a expressão de Jacques Fontaine, citado por Deproost ${ }^{8}$. Não será, pois, estranha a quantidade de manuscritos do texto aratoriano que circulavam nas diversas partes da Europa ${ }^{9}$ durante o período medieval (McKinlay contabiliza quase centena e meia de códices). A análise dos manuscritos mostrou a McKinlay também um outro facto de grande relevo: a associaçáo do poeta a outros autores das mais diversas áreas. Ora, tal facto prova que o texto ultrapassa o campo estritamente religioso e que era importante em domínios como a Filosofia, a Geografia, a História, entre outros ${ }^{10}$; ou seja, a obra de Arátor tem, de facto, uma dimensão universalizante, épica.

Nesta curtíssima investida pela recepção de Arátor durante os tempos medievais, sobre a qual Deproost e

${ }^{8}$ Cf. Deproost 1990 305: "[...] les programmes de l'école médiévale, au moins jusqu'en 1200, ont effectivement compté Arator parmi les poetae scholastici, pour former, avec Juvencus, Prudence et Sédulius, ce que Jacques Fontaine a pu appeler le «nouveau quadrige des épopées bibliques»". Vd. ainda Fontaine 1981287.

${ }^{9}$ Cf. McKinlay 1942 118: "By way of résumé we note that are some thirty-one places including forty-four manuscripts of Arator which can be identified with some certainty as their sources of provenience. These localities are distributed over seven countries: Great Britain (England) with four; France with thirteen; Belgium, Luxembourg, Bohemia with one each; Italy with one, possibly two; and Germany with nine".

${ }^{10}$ Cf. McKinlay 1942 104: "If the student will run his yes over the codices of this volume, he will get some idea of what part Arator played in the intellectual and emotional apparatus of the Middle Ages. [...] He will find him associated a bit of science here and there, with the liberal arts including such studies as history, geografy, and philosophy". 
McKinlay se debruçam aturadamente nas obras citadas, encontramos justificação plena para o minucioso estudo que o humanista português Aires Barbosa, quase mil anos depois da apresentação do poema, dedicou à História apostólica. Em Salamanca, no ano de 1516, o aveirense fez vir a lume, numa obra de cento e cinquenta e um fólios, um comentário detalhado acerca do poema do vate cristão, acompanhado do texto original, e que o eminente latinista Walter de Medeiros define nestes termos:

Com meticulosidade extrema, o humanista comenta, quase palavra a palavra, os 2.325 hexâmetros da História apostólica; e as digressóes que se permite ainda mais avolumam as proporçôes da obra. Embora o gosto da época se satisfizesse com este emaranhado de questōes gramaticais, arqueológicas, históricas, jurídicas, filosóficas e teológicas, já entấo houve quem achasse o Mestre Grego de excessiva prolixidade. Mas ele foi respondendo que só os néscios se queixam da abundância: o seu comentário destinava-se a estudantes e a eruditos - e uns e outros achariam nele o que buscassem ${ }^{11}$.

Trata-se, efectivamente, do primeiro e, tanto quanto julgamos, do mais completo estudo acerca da História apostólica, na medida em que abarca toda a obra. Não obstante, o comentário barbosiano não tem granjeado a atenção merecida, já que só marginalmente os estudiosos de Arátor lhe fazem curtas referências ${ }^{12}$.

${ }^{11}$ Vd. Medeiros 195371.

12 Não deixa de causar estranheza que, numa obra de três 
Barbosa utiliza a primeira edição impressa da obra de Arátor, a do veneziano Aldo Manúcio, saída em 1502, que contempla também alguns dos mais insignes poetas cristãos. Não deixa de ser pertinente que Manúcio apenas inclua comentários biobibliográficos acerca de dois autores, a saber, Arátor e Sedúlio, o que é revelador da afeição do célebre editor italiano por dois dos mais destacados cultores da epopeia bíblica. Igualmente assinalável é o facto de o poema de Arátor ter sido repetidamente editado e minuciosamente estudado no primeiro quartel de Quinhentos, onde a imprensa era ainda rudimentar e havia grande triagem de autores.

Nos séculos posteriores, a obra de Arátor foi reeditada com frequência, oscilando o seu título entre Historia apostolica, De Actibus apostolorum e In Apostolorum acta ${ }^{13}$. Até à edição de McKinlay, no CSEL, a edição mais referenciada é sem dúvida a de Arntzen ${ }^{14}$, de 1769, reimprimida um século mais tarde (em 1866) na Patrologia Latina de Migne (PL 68 col. 45-252). As informaçôes dadas pelo filólogo neerlandês no Praefatio

centenas e meia de páginas, consagrada fundamentalmente ao estudo do primeiro livro de Arátor, Deproost diga, sobre o humanista português, as palavras tão escassas e dúbias que a seguir transcrevemos: "[...] enfin, on connaît un commentaire latin imprimé du savant et poète portugais Ayres Barbosa, publié à Salamanca en avril 1516, sans doute à l'occasion d'un enseignement qu'il dispensa dans cette université" (Deproost 1990 304).

${ }^{13}$ McKinlay (1951 VII-VIII) regista dez ediçôes impressas da obra de Arátor (número que peca por escassez) que oscilam entre estes três títulos.

${ }^{14}$ Preferimos o nome original do filólogo neerlandês, Henri-Jean Arntzen, ao nome latinizado pelo qual é mais conhecido, Arntzenius. 
(col. 45-57) são dados preciosos acerca da vida e obra de Arátor e ainda hoje constituem ponto de partida incontornável no conhecimento do nosso vate ${ }^{15}$. Por outro lado, trata-se de uma edição abundantemente anotada com variantes do texto, comentários de diversa ordem, remissóes para as fontes, entre outros ${ }^{16}$.

Foi, no entanto, a edição de McKinlay que abriu novos caminhos para um estudo mais aprofundado da obra e que despertou o interesse por um autor que, como ficou provado, foi apreciado e imitado durante toda a Idade Média. Dois trabalhos nos merecem especial referência neste contexto: o primeiro, da autoria de PaulAugustin Deproost, reflecte sobre o tratamento da figura de S. Pedro no primeiro livro, e tem por título L'apôtre Pierre dans une épopée du VI siècle. L'Historia apostolica" d'Arator; o segundo, intitulado Arator On the Acts of the apostles: a baptismal commentary, da responsabilidade de Richard Hillier, analisa a projecção do sacramento do baptismo no texto aratoriano, considerando ser essa a trave-mestra da construção do poema. E a tendência é, efectivamente, a de justiçar Arátor, colocando-o entre os grandes poetas épicos cristãos, como sugere a obra de Roger P. H. Green, Latin Epics of the New Testament: Juvencus, Sedulius, Arator, saída em 2006. Finalmente, impóe-se sublinhar a recente edição da epopeia de Arátor

${ }^{15}$ A este propósito devemos referir que quase todos os estudos modernos acerca de Arátor fazem extensas referências e citaçóes do Prefácio de Arntzen.

${ }^{16}$ Embora posterior, em nada se assemelha à de Arntzen a edição do italiano Giuseppe Ludovico Perugi, vinda a lume em 1908, que se limita a transcrever o poema aratoriano e a anotar algumas variantes dos manuscritos. 
(2006), sob a coordenação de A. P. Orbán, incluída no Corpus Christianorum, Series Latina (CCSL 130-130A). Esta edição, por ser a mais recente e a mais abalizada, serviu-nos de base para a tradução da Historia apostolica que agora apresentamos.

\section{ARÁTOR: DE FUNCIONÁRIO DA CORTE A HOMEM DA IGREJA}

Arátor nasceu por volta de 490 e morreu por volta de 550; era natural da província da Ligúria, não se podendo definir ao certo qual a cidade que lhe serviu de berço, muito embora Miláo ou Pavia se perfilem entre as mais prováveis. Na verdade, é tarefa penosa e náo isenta de especulaçôes reconstituir a vida de um autor do qual pouco mais se sabe além do que consta na própria obra. Arátor legou-nos a sua História apostólica em versos hexâmetros, que fez acompanhar de três epístolas em dísticos elegíacos, dirigidas, a primeira ao papa Vigílio, a quem dedica o poema; a segunda ao abade Floriano, o revisor da sua obra e a quem pede uma espécie de nihil obstat ${ }^{17}$; e a terceira a Parténio, um amigo que o terá incentivado a dedicar os seus versos à causa cristá. Às informaçôes que respigamos da análise da obra aratoriana, devemos acrescentar a preciosa carta do rei Atalarico, registada por Cassiodoro nas Variae (8.12), dirigida precisamente ao nosso poeta, e ainda alguns dados que podemos colher de três cartas de Enódio (Ep. 8.4; 8.11; e 9.1) e de duas Dictiones (9 e 12) do mesmo autor.

${ }^{17}$ Cf. Arator Ad Flor. 5: ad carmen concurre meum; 10: maxima cum teneas, et breniora lege; e 24: cede dies operi. 
Centremo-nos, então, nas informações transmitidas pelos dois autores contemporâneos de Arátor. Cassiodoro, intérprete oficial da corte ostrogoda, com sede em Ravena, regista nas Variae uma carta do rei Atalarico (Var., 8, 12), escrita provavelmente em 526, com o seguinte destinatário: Aratori uiro illustri. Se juntarmos a este dado a dedicatória da Dictio 18 de Enódio, Data Aratori V[iro] C[larissimo], tudo nos leva a pensar que o poeta ocuparia uma posição social elevada e que, possivelmente, pertenceria à ordem senatorial, muito embora se possam ter algumas reservas a este respeito, como sublinha Deproost ${ }^{18}$. A carta é um extenso panegírico a Arátor: destinava-se a reconhecer os excelentes serviços por ele prestados durante o reinado de Teodorico, que lhe havia conferido o título de comes domesticorum (comitiua domesticorum illustratum), destacando o brilhantismo com que liderara uma embaixada do povo da Dalmácia junto do rei $^{19}$. Mas a carta também lhe confere novo título, não especificado por Cassiodoro no final da missiva. Ora, um dos códices

${ }^{18}$ Cf. Deproost 1990 22: 'La dédicace d' une dictio d'Ennode à son protégé l'appelle uir clarissimus, ce qui laisse entendre qu'Arator appartenait à l'ordre sénatorial, et ce dès l'année 506 [...]; de plus, la mention uir illustris que l'on trouve dans d'autres témoignages, et notamment dans la lettre d'Athalaric [...] semble indiquer qu'Arator siégeait effectivement au Sénat, encore qu'il faille ici être prudent: [...] le titre de uir illustris n'impliquait pas nécessairement qu'ils devinssent membres du Sénat”.

${ }^{19}$ Vd. Cass. Var. 8.12: Directus enim de partibus Dalmatiarum ad domnum auum nostrum sic necessitates prouincialium, sic utilitates publicas allegabas, ut apud illum magna cautela sollicitum et copiosus esses et fastidia non moueres. Arntzen (PL 68 col. 51) situa a embaixada no ano 526, pouco antes da morte de Teodorico. 
que regista a obra de Arátor vem acrescentar ao título de comes domesticorum o de comes priuatorum ${ }^{20}$, "o mais alto cargo civil oficial na corte de Ravena" ${ }^{21}$, como afirma Deproost.

Se é incerto o local de nascimento do nosso poeta, a carta de Cassiodoro diz-nos claramente que era originário da regiáo da Ligúria, ao afirmar que não foi em Roma que Arátor aprendeu o seu persuasivo latim e que também a Ligúria tem os seus cíceros:

Romanum denique eloquium non suis regionibus inuenisti et ibi te Tulliana lectio disertum reddidit, ubi quondam Gallica lingua resonauit. Vbi sunt, qui Latinas litteras Romae, non etiam alibi asserunt esse discendas? [...] mittit et Liguria Tullios suos ${ }^{22}$.

Segundo a mesma missiva, o pai de Arátor, que também pertencia à corte ostrogoda, terá sido o seu primeiro mestre e, tal como o filho, era um excelente retórico e um brilhante homem de letras:

${ }^{20}$ Vd. Codex Paris., B. N., lat. 9347, f. 75': [...] oblatus huiusmodi hic codex ab Aratore inlustri excomite domesticorum excomite priuatorum uiro religioso subdiacono sanctae ecclesiae Romanae sedis apostolicae.

${ }^{21}$ Cf. Deproost 1990 23, tradução nossa.

${ }^{22} \mathrm{Vd}$. Cass. op. cit. Moricca alerta para o facto de um inexacto conhecimento da divisão da província da Ligúria ao tempo dos Ostrogodos ter conduzido alguns ensaístas a darem a naturalidade genovesa a Arátor. Mas a Ligúria compreendia a actual Lombardia e abrangia também as cidades de Miláo e Pavia, pelo que outros ensaístas, informa ainda Moricca, fazem nascer o vate cristão naquelas duas últimas cidades (Moricca 1932: 209). Relativamente a esta questão, vejam-se as reflexôes de Arntzen no prefácio à edição da História apostólica (PL 68 col. 49-50) e as consideraçóes de Perugi (1908 8-10). 
Genitoris quin etiam tui facundia et moribus adiuuaris, cuius te eloquium instruere potuit, etiamsi libris ueterum non uacasses. Erat enim, ut scimus, egregie litteris eruditus. [...] paterno igitur exemplo ingenium extendisse credendus es, qui in Romano foro eloquentiam non nutristi. O beatum magistrum felicissimumque discipulum [...]? $?^{23}$

A Dictio 9 de Enódio, recitada quando Arátor foi admitido na escola de Deutério em Milão ${ }^{24}$, informa-nos de que Arátor ficou órfão de pai muito cedo e foi entregue aos cuidados do próprio Enódio e de Lourenço Litta ${ }^{25}$, bispo de Miláo entre 490 e $511^{26}$. E parece que, já nesta cidade, o futuro autor da História apostólica se mostrava mais inclinado para a poesia do que para a retórica ${ }^{27}$. A

${ }^{23} \mathrm{Vd}$. Cass. op. cit.

${ }^{24}$ Cf. Ennod. Dict. 9: Si scrutatus penitus fueris latentium secreta camporum, inuenies illic Deuterium, qui ubertate linguarum germina tibi multiplicatis seminibus et sudorem remuneretur impensum.

${ }^{25}$ Cf. Ennod. ibid.: Orbum parentibus dixi, cui per felicia naturae damna communis pater et episcopus factus est proprius. [...] Et illud domni Laurentii quod mundi necessitatibus succurrit ingenium in ministerio huius exercetur infantuli. [...] Quem non iuuet amisisse patrem, sub lucrosa commutatione si talem conceditur inuenisse? Riché salienta a importância de Enódio na instrução de muitos jovens, que diversas famílias importantes de toda a Itália entregavam aos seus cuidados, e, ainda que não se possa falar de uma "Escola de Enódio", a sua cultura literária granjeou-lhe grande renome como mestre e como homem de letras. Cf. Riché 199526.

${ }^{26}$ Estas datas são importantes, pois permitem-nos datar o nascimento de Arátor por volta do ano 490, data sem grande sustentabilidade documental, mas ainda assim defendida, entre outros, por Arntzen (PL 68 col. 49) e Perugi (1908 10-11).

${ }^{27}$ Baseando-se na Dictio 12 de Enódio, Moricca afirma o seguinte: "[...] ma forse gli piaceva più la poesia che la retórica, perchè, alla vigília del giorno in cui doveva recitare la sua tesi, ne diede l'incarico 
influência de Enódio, bispo de Pavia em 514, ter-lhe-á aberto, mais tarde, as portas da corte ostrogoda, em Ravena. Convém, de resto, salientar que Enódio nutriu por Arátor uma estima e uma admiração que vão para lá da simples relação mestre-discípulo, evidente nos vários textos dedicados ao vate cristão ${ }^{28}$.

Em Ravena, Arátor continuou a sua formação, tendo-se tornado um brilhante advogado ${ }^{29}$ e diplomata, a acreditar nas palavras da carta de Cassiodoro, que não regateia elogios ao seu saber e à sua eloquência:

[...] qui parem in suis studiis non haberet. [...] Aduocationis te campus exercuit: te iudicii nostri culmen elegit. [...] Abundantia siquidem uerba cum suauissimo lepore defluebant et cum finem faceres, adhuc dicere quaerebaris: delectando, mouendo, implebas magis ueri oratoris nisum, cum iam causidici deseruisses officium ${ }^{30}$.

Arátor conseguiu, pois, um certo prestígio na corte de Teodorico, continuando o seu sucessor, Atalarico, a conferir-lhe honras importantes, tal como a missiva sugere. Mas é também em Ravena que Arátor

ad Ennodio, che la scrisse per lui" (1932 209-210).

${ }^{28}$ Vd. Ennod. Ep. 8.4, 8.11 e 9.1; e Dict. 9, 12, 17 e 18. Enódio dedica até um singelo poema pleno de afecto ao nascimento de Arátor: In natalem infantis Aratoris (Carm. 2.105). Fontaine vai mesmo ao ponto de afirmar que Arátor "parece ter sido o seu aluno de predilecção" (1981 263, nota 561, tradução nossa).

${ }^{29}$ Riché, face à escassez de dados, aponta mesmo o caso de Arátor para afirmar a existência de escolas, em Ravena, nomeadamente na área do direito: "Le droit y devait être enseigné, ce qui decida Arator, destiné à la carrière d'avocat, à s'y rendre" (Riché 1995 27).

${ }^{30} \mathrm{Vd}$. Cass. op. cit. 
vai estabelecer fortes laços de amizade com Parténio ${ }^{31}$, a quem dirige uma carta composta por cinquenta e um dísticos elegíacos, ordinariamente colocada no final da História apostólica como uma espécie de posfácio. Nesta epístola, Arátor começa por reconhecer em Parténio a sua excelência de carácter e de dons oratórios, constituindo os primeiros trinta versos um extenso panegírico revelador da admiração nutrida por Arátor em relação àquele que, de algum modo, foi também seu mestre ${ }^{32}$. Mestre, na medida em que, sob a supervisão de Parténio, Arátor aprendera a ler os clássicos ${ }^{33} \mathrm{e}$, mais importante ainda, havia sido Parténio quem o incentivara à leitura dos poetas cristãos, como Ambrósio, Dracôncio ou Sidónio ${ }^{34}$. Na verdade, o poeta, que se comprazia em versejar sobre mitologia ${ }^{35}$, parece ter recebido de Parténio o incentivo para colocar a sua verve poética ao serviço da causa cristá:

${ }^{31} \mathrm{Vd}$. Arator Ad Part. 35-36: his quoniam Laribus tenebamur in urbe Rauennae, / hospes hians aderam nocte dieque tibi.

${ }^{32} \mathrm{Vd}$. ibid. 11-14: Quis bona tanta canat? Breuiter loquor; omnia tecum / quae faciunt magnos singula solus habes. I Tu, facunde, sonas Rhodani Rhenique cateruis; I regia dulcisonum te probat aula uirum.

${ }^{33} \mathrm{Vd}$. ibid. 37 e 39: Quos mihi tu libros, quae nomina, docte, sonabas! / [...] Caesaris Historias ibi primum te duce legi.

${ }^{34} \mathrm{Vd}$. ibid. 43-48: Sed tamen ad ueros remeabas, optime, uates, / quorum metra fides ad sua iura trahit, / [...] Ambrosius [...], Decentius [=Dracontius?], [...] [Sido]niana chelys. Seguimos a transcriçáo de Fontaine, que, apesar de tudo, manifesta algumas dúvidas na correcção de Decentius para Dracontius (Fontaine 1981 261, nota 553).

${ }^{35} \mathrm{Vd}$. Arator Ad Part. 49-52: Cura mibi dudum fuerat puerilibus annis / uersibus assiduum concelebrare melos, / scribere quas etiam simulauit fabula partes / et per inane fretum sub leuitate rapi. 
"O utinam malles" dixisti "rectius huius / ad Domini laudes flectere uocis iter, / [...]" Constitui, fateor, si quando forte mererer / ingenii fructus ad meliora sequi ${ }^{36}$.

Arátor seguiu o conselho e, depois de entrar ao serviço da Igreja, procurou saborear as páginas bíblicas ${ }^{37}$, sendo particularmente cativado pela figura de S. Pedro e pelos Actos dos apóstolos, sobre os quais incide o seu poema ${ }^{38}$. No final da missiva, o vate manifesta grande confiança na qualidade e na fortuna da sua obra e, concomitantemente, na glória do seu impulsionador, Parténio ${ }^{39}$.

Arátor deixa a vida de corte em Ravena e envereda pela carreira eclesiástica na qualidade de subdiácono, em Roma. Quando, não sabemos ao certo; todavia, os primeiros versos da carta a Vigílio deixam-nos entender que a sua entrada na Igreja coincidiu com o início do pontificado do novo papa (depois de Março de 537), uma vez que alude ao cerco imposto a Roma por Vitiges em 537, no contexto da guerra entre Bizâncio e os Ostrogodos:

Moenibus undosis bellorum incendia cernens, / pars ego tunc populi tela pauentis eram. I Publica libertas, sanctissime papa

${ }^{36} \mathrm{Vd}$. ibid. 55-56 e 59-60.

${ }^{37} \mathrm{Vd}$. ibid. 69-70 e 73-74: Namque ego, Romanae caulis permixtus amoenis / ecclesiae, tonso uertice factus ouis, / [...] et nunc Dauiticis assuetus floribus odas / mandere, nunc Genesim mens cupiebat edax.

${ }^{38} \mathrm{Vd}$. ibid. 77-78 e 83-84: Incidit ille mihi, quem regula nominat Actus, / messis apostolicae plenus in orbe liber; [...] Huius [Petri] ab historia produxi carmina tiro / pastorique meo sedulus ora dedi.

${ }^{39}$ Vd. ibid. 95-96 e 101: Huius ad Italiae tendit laudatio fines, I atque ultra patriam gloria nomen habet; [...] Ibimus ambo simul, quo pagina uenerit ista. 
Vigili, / aduenis incluso soluere uincla gregi. / [...] Ecclesiam subeo dimissa naufragus aula; / perfida mundani desero uela fret ${ }^{40}$.

O poeta, falando na primeira pessoa, vê do alto das muralhas romanas cercadas, que se lhe assemelham a ondas (moenibus undosis), o horror da guerra e, numa nota biográfica rara, diz-nos que ele "fazia parte desse povo aterrorizado pela guerra" ${ }^{41}$. Com a chegada do novo papa, Vigílio, Arátor renuncia à vida mundana (perfida mundani desero uela freti), abandonando a corte (naufragus aula) e ingressando na Igreja como subdiácono, pois é assim que ele nos é sempre apresentado. Já no contexto da guerra entre os Godos e os Bizantinos, Arátor terá deixado para trás a incerteza de uma Ravena marcada por convulsóes políticas e por um forte sentimento anti-romano e optado pela segurança da vida eclesiástica em Roma. Cassiodoro, também ele "cada vez mais interessado nas questóes religiosas" faz um trajecto semelhante e, abandonando a corte ostrogoda, reúne esforços com o papa Agapito para fundar em Roma, em 535, uma espécie de universidade cristá, conhecida como Biblioteca de Autores Eclesiásticos, dada a ausência de estudos religiosos na cidade ${ }^{43}$. É bem possível que Arátor também tenha estado ligado a este projecto, como especula Hillier ${ }^{44}$.

${ }^{40} \mathrm{Vd}$. Arator Ad Vig. 1-4 e 9-10.

${ }^{41} \mathrm{O}$ cerco referido é quase consensualmente identificado como o longo cerco que Vitiges impôs aos Romanos nos anos 537-538. Cf., v.g., Richard Hillier 1993 10-11.

${ }^{42} \mathrm{Vd}$. Riché 1995113.

${ }^{43}$ Cf. ibid. 112-115.

${ }^{44}$ Cf. Hillier 1993 11, nota 19. 
As últimas notícias de Arátor surgem no prefácio de um manuscrito (Vatican., Pal. Lat. 1716 [SX], fl. 1) que descreve minuciosamente como a História apostólica foi recebida, apreciada e recitada em Roma ${ }^{45}$. A 6 de Abril de 544, Arátor apresentou a sua obra na basílica de S. Pedro ao Sumo Pontífice, estando presentes os mais altos dignitários da Igreja. O manuscrito foi guardado no escrínio da igreja, por iniciativa de Surgêncio, o prefeito do arquivo pontifício. No entanto, foi de imediato solicitado que fosse feita uma leitura pública do poema, tal era o seu interesse. A récita pública da obra pelo próprio autor, com um vasto auditório de clérigos e laicos, viria a ter lugar na Igreja de S. Pedro ad Vincula, em quatro sessôes, entre Abril (13 e 17) e Maio (8 e 30) desse ano. Houve, pois, como sublinha Deproost, duas cerimónias bem distintas: a primeira destinouse a apresentar o manuscrito a um auditório selecto, com o papa incluído, que apreciou o poema e propôs a recitação pública do mesmo; a segunda destinou-se a apresentar publicamente a História apostólica ao povo romano, que a aplaudiu com entusiasmo ${ }^{46}$.

É aqui que terminam as notícias acerca do poeta de quem, depois de 544, nada sabemos. Terá morrido por volta de 550, ou entáo de 560, como sustentam

45 O documento é registado por McKinlay (1951 XXVIII). Também Aires Barbosa refere parcialmente tal testemunho, apoiando-se nas informaçóes de Aldo Manúcio (vd. Barbosa 1516 fl. iii vo , 1. 50-56). Châtillon analisa com extrema minúcia todo o documento (1963 70-128).

${ }^{46}$ Cf. Deproost 1990 32-33. 
alguns estudiosos ${ }^{47}$. No entanto, os seus últimos anos de vida terão estado ligados a um período histórico conturbadíssimo, em que a História apostólica também terá desempenhado um papel de relevo.

\section{Os feitos de S. Paulo na História apostólica}

A descrição em verso da gesta evangelizadora dos dois pilares da Igreja, Pedro e Paulo, constitui o tema central da História apostólica, um extenso carme apresentado ao papa Vigílio no ano 544. Arátor, o seu autor, dividiu-a em dois livros: no primeiro relata os feitos de S. Pedro; o segundo é dedicado a S. Paulo, aproveitando para juntar nos versos finais os dois apóstolos, ao relatar a sua irmandade através do martírio. O presente trabalho diz respeito ao segundo livro e pensamos ter particular interesse num momento em que a Igreja acaba de celebrar o Ano Paulino. Entendemos acrescentar-lhe as três cartas que acompanham a obra, pois, como já se disse, nelas se dá a conhecer, na primeira pessoa, o autor e as motivaçôes do seu trabalho.

Descrita pelo próprio autor como uma versão dos Actos dos apóstolos em verso, a História apostólica vai seguindo o texto lucano, filtrando-o pelo crivo épico, o que faz de Arátor um dos grandes cultores da epopeia bíblica, na senda de Prudêncio, Sedúlio e Juvenco. A omissão de certas acções e personagens bíblicas, a ampliação de alguns episódios ou o acrescento de outros são apenas alguns aspectos que distanciam esta obra do

${ }^{47}$ A primeira data é defendida por Thraede (1961 187); a segunda é proposta por Moricca (1932 211). 
seu modelo. Por outro lado, não é estranha à História apostólica a influência das epopeias clássicas, como a Eneida ou a Farsália, nomeadamente a nível vocabular.

Nesta narrativa épica, encontramos um narrador particularmente interventivo, interpondo pari passu a sua apreciação dos factos. A Arátor interessa relevar a acção evangelizadora de Paulo, destacar todos os traços concorrentes na sua heroicização, mas também esclarecer os leitores acerca de algumas matérias teológicas e dogmáticas controversas no seu tempo. Como disse Fontaine, "enquanto homem da Igreja, Arátor não se coibia de pregar do alto dos seus versos" 48 . $\mathrm{E}$, neste ponto, assume particular relevância a questão do baptismo, constantemente explorada sobretudo pela vertente da figuração do baptismo de Cristo na história veterotestamentária.

O segundo livro da História apostólica, integralmente consagrado à gesta de S. Paulo, está dividido em dezanove partes ou secçóes, cujo conteúdo se fundamenta nas informações dos Actos dos apóstolos, desde o capítulo 13 até ao final. Assim, na secção 1 (vv. 1-39; Act. 13.1-12), Saulo, doravante chamado Paulo, é convocado pelo Espírito Santo para a pregação e chega a Pafo, onde Sérgio Paulo era procônsul. Um mago tenta impedir a pregação do Apóstolo, mas este inflige-lhe a cegueira. Face a tal prodígio, o procônsul converte-se.

Na secçáo 2 (vv. 40-95; Act. 13.13-26), Paulo chega a Antioquia e fala na sinagoga aos Judeus. $\mathrm{O}$ seu longo discurso aborda, por um lado, a saída dos

${ }^{48} \mathrm{Vd}$. Fontaine 1981: 262, tradução nossa. 
Israelitas do Egipto, a travessia do mar Vermelho, a penosa peregrinaçáo e os milagres no deserto e, por outro, o testemunho dado por João Baptista acerca de Jesus. Arátor apela à conversão da Judeia, bafejada com tantos milagres e, ainda assim, ímpia e sem fé.

Na seç̧áo 3 (vv. 96-155; Act. 13.27-50), Paulo continua o seu discurso na sinagoga de Antioquia, falando sobre a paixão, o sepulcro e a ressurreição de Cristo. Alguns judeus convertem-se, mas outros proíbem-no de falar. Paulo, indignado, decide dirigir a sua pregação aos gentios. Arátor, inspirado pelas censuras de Paulo, recorda os dois filhos de Rebeca como símbolos de dois povos, o judeu e o cristão, sendo Jacob superior a Esaú, embora fosse este o primogénito.

Na seç̧áo 4 (vv. 156-241; Act. 14.8-18), Paulo cura, em Listra, um coxo de nascença. A multidão, face ao prodígio, considera-o um deus e prepara-se para lhe oferecer sacrifícios, no que é asperamente repreendida pelo Apóstolo, que faz a condenação de toda a espécie de idolatria. Arátor coteja este milagre de Paulo com o de Pedro (Act. 9.33-35), ressalvando a diferença de um coxo ser gentio e o outro judeu. Fica assim salientado o papel de Paulo enquanto evangelizador dos gentios e o de Pedro como conversor dos Judeus.

A secção 5 (vv. 242-306; Act. 15.1-12) dá conta da grande controvérsia sobre a obrigação de se observar a lei de Moisés, particularmente se o baptismo podia ser concedido aos náo circuncidados (os gentios). Paulo dirige-se a Jerusalém a fim de consultar os apóstolos, nomeadamente Pedro, acerca desta questâo. $\mathrm{O}$ discurso 
de Pedro reforça a posição de Paulo, ao afirmar a náo obrigatoriedade da circuncisáo para os gentios que se convertessem ao Cristianismo. Arátor refere-se à circuncisão de Abraáo como o estabelecimento de uma aliança antiga entre Deus e o povo eleito, mas que convém agora ver na sua simbologia.

$\mathrm{Na}$ secçáo 6 (vv. 307-382; Act. 16.6-10), o Espírito Santo proíbe Paulo de pregar na Ásia, e o Apóstolo dirige-se à Macedónia, pois, numa visão, um macedónio implora-lhe os seus serviços apostólicos nessa regiáo. Apenas os nove versos iniciais da secção glosam o texto lucano, dedicando Arátor os restantes sessenta e sete a uma extensa digressão. Justifica a rejeição de uns e a escolha de outros por parte de Deus através do exemplo evangélico, quando Cristo rejeita um seguidor entusiasmado e chama um outro que estava em silêncio (Lc. 9.57-62). Seguidamente, amplia o tema para a questáo da chamada ao sacerdócio: coteja o sacerdócio levítico com o eclesiástico e discute a castidade a que os Levitas não estavam obrigados, cumprindo uma série de rituais que passavam pelas próprias vestes sacerdotais, e à qual se devem sujeitar os servidores da Igreja, cujos filhos são os crentes que nascem da semente da palavra.

Na secçáo 7 (vv. 383-442; Act. 16.16-34), uma jovem pitonisa exclama em Filipos que Paulo é servo do Deus altíssimo. Paulo expulsa o demónio que a possuía, mas os senhores da pitonisa, indignados pela perda do lucro proveniente da arte divinatória da rapariga, incitam a multidáo contra Paulo, que é preso juntamente com Silas. Ocorre de noite um violento tremor de terra 
que abre as portas das celas. $\mathrm{O}$ carcereiro, acordando e julgando que os prisioneiros se tinham evadido, decide pôr termo à vida, mas Paulo sossega-o. Perante tal atitude, o carceiro converte-se e é baptizado com todos os de sua casa.

Na secçáo 8 (vv. 443-505; Act. 17.16-34), os Atenienses zombam de Paulo chamando-lhe "semeador de palavras”. O Apóstolo discursa no Areópago, fazendo um elogio à sabedoria eà religiosidade do povo de Atenas, que até construiu um altar "ao deus desconhecido". É esse deus verdadeiro que Paulo lhes anuncia agora, pelo que apela à renúncia ao culto dos ídolos feitos de vil metal. Perante tais palavras, convertem-se alguns, como Dionísio Areopagita, mas os epicuristas e os sofistas troçam da sua pregação. $\mathrm{O}$ poeta aproveita, então, para explicar sumariamente os motivos dessa rejeição.

Na secçáo 9 (vv. 506-568; Act. 18.1-11), Paulo chega a Corinto e hospeda-se em casa de Áquila, seu companheiro de ofício, já que ambos eram fabricantes de tendas. Cristo, aparecendo ao Apóstolo, exorta-o a não desistir da pregação naquela cidade. Durante três quartos desta secção, o poeta examina a simbologia dos factos bíblicos resumidos nos primeiros quinze versos. Debruça-se, primeiramente, sobre o nome do anfitriāo de Paulo, Áquila, figurativo da renovação baptismal, pois também a águia rejuvenesce quando, na sua velhice, mergulha nas águas. Detém-se, depois, na simbologia da profissão de Paulo, que constrói as tendas da salvação para os homens, expulsos da casa de Deus pelo pecado. Finalmente, Arátor coteja os ofícios dos dois heróis do 
seu poema: enquanto Pedro pesca novas almas para o mar da graça, Paulo ensina, pelo dom da palavra, a edificar as tendas celestes que hão-de salvar os homens.

$\mathrm{Na}$ secçáo 10 (vv. 569-622; Act. 19.1-7), Paulo encontra em Éfeso alguns homens a quem pergunta se já tinham sido baptizados. Como estes lhe dissessem que tinham recebido o baptismo de João, o Apóstolo baptiza-os em nome de Jesus, tendo aqueles começado imediatamente a falar várias línguas. Também nesta secção o poeta se espraia na interpretação do passo bíblico, que resume nos oito primeiros versos. A gravidade do assunto leva-o mesmo a solicitar o auxílio divino, em jeito de invocação: "Tu, Espírito Divino, molha agora com maior abundância / os lábios meus, para que os ensinamentos que me concedeste / sejam dignos de ti!" (vv. 579-581). Recorda, então, o baptismo de Cristo por João e o testemunho deste, ao afirmar o baptismo de Cristo como o único e o verdadeiro. Arátor insurgese contra os ímpios e os hereges que acreditam tratarse de um duplo baptismo aquele que Paulo ministrou aos doze efésios. Finalmente, afirma que o baptismo concedido em nome de Cristo, ainda que seja dado por um herege, é definitivo, não havendo, em caso algum, necessidade da sua repetição. No final da secção, o poeta insiste na simbologia do número doze, que, por ser um múltiplo de três, é figurativo da Trindade: eram doze os baptizados por Paulo, doze os cestos na multiplicação dos pães, doze os apóstolos.

Na secçáo 11 (vv. 623-687; Act. 19.11-19), Paulo realiza admiráveis prodígios entre os Efésios, bastando 
aos doentes tocar nas suas vestes para ficarem sarados. Entretanto, sete judeus invocam o nome de Cristo, pregado por Paulo, para expulsar um demónio. Este responde-lhes que conhecia a Cristo e a Paulo, mas não a eles, e agride-os tão violentamente que os deixa nus e dilacerados. Perante tais acontecimentos, muitos correm a receber o baptismo, e outros queimam livros de magia, estimados em cinquenta mil moedas. Arátor comenta a simbologia e a sacralidade deste número, pois também a cada cinquenta anos se celebrava o Jubileu, e a arca do dilúvio tinha cinquenta côvados.

$\mathrm{Na}$ secçáo 12 (vv. 688-752; Act. 19.23-40), Demétrio, que construía sacrários em prata para Diana, vendo a sua arte em perigo pela pregação de Paulo, incita a multidão contra este com o argumento de que Paulo atentava contra os deuses antigos e sobretudo contra Diana, protectora dos Efésios. O povo é convencido e, em gritos de aclamação à deusa, arrasta Paulo para o teatro. No entanto, a confusão acaba por se desvanecer, sem deixar qualquer rasto. Arátor insurge-se contra a loucura da multidão, desmonta a argumentação de Demétrio e, apoiando-se no Antigo Testamento, afirma que o ouro e a prata a oferecer a Deus náo devem ser os ídolos, mas a fé do coração e a pureza das palavras.

Na secçáo 13 (vv. 753-825; Act. 20.7-12), em Tróia, Paulo discursa durante a noite numa sala do terceiro andar. Um jovem, chamado Êtico, dominado pelo sono, cai de uma janela até ao primeiro andar e morre. Acode Paulo e acalma a multidão chorosa, dizendo que o jovem estava vivo. Imediatamente, este 
ressuscita. Dois comentários merecem a Arátor tais factos bíblicos: o primeiro é que o poder de ressuscitar os mortos, outorgado por Cristo aos seus servidores, resulta da vitória de Cristo sobre a morte, em virtude da sua ressurreição; em segundo lugar, Arátor acredita que todo este episódio, assim como a própria imagem da Igreja, estão figurados na descrição da Arca de Noé, com o andar superior reservado aos homens, o seguinte aos animais domésticos e o inferior aos selvagens. $\mathrm{O}$ universalismo da Igreja admite todos os povos e naçóes, mas a salvação só se encontra no andar superior, daí que Paulo tenha reconduzido Êtico ao terceiro andar, depois de o ressuscitar.

$\mathrm{Na}$ secção 14 (vv. 826-912; Act. 20.17-38), prestes a embarcar rumo a Jerusalém, Paulo despedese dos anciãos de Mileto com um discurso pleno de emoção. Recorda-lhes os seus ensinamentos, incita-os a continuarem activamente a sua acção evangelizadora e despede-se para sempre, dizendo-lhes que, em Jerusalém, iria enfrentar duras provaçôes. Partindo das palavras de Paulo, que dissera ter evangelizado "durante três anos, dia e noite” (v. 888), Arátor afirma que os livros que versam sobre matérias sagradas (como o seu) devem ecoar um tríplice sentido: "o histórico, o moral e o tipológico" (v. 891). É, pois, com base neste último sentido que o poeta faz a apologia da Santíssima Trindade, figurada em diversos passos bíblicos: nas seis vasilhas (o dobro de três) das bodas de Caná, que continham três medidas; na antiga forma de sacrifício, que previa três espécies de pão; no acompanhamento durante três milhas e na dádiva de 
três pães, que Cristo aconselhava aos seus seguidores. Insurge-se, finalmente, contra a "estéril Judeia" que não soube reconhecer aqueles sinais e, consequentemente, não aceitou a fé na Trindade, ao negar o Filho.

Na seç̧áo 15 (vv. 913-991; Act. 21.27-40; e 22.1-24), Paulo é surpreendido e maltratado por um grupo de judeus, quando se aproximava do templo. É salvo pela chegada do tribuno, que ordena aos soldados que o acorrentem. Paulo, nos degraus do templo, faz um discurso em hebraico, onde recorda que ele próprio já foi perseguidor dos Cristãos, mas um prodígio o fez converter-se e ser agora mensageiro de Deus. Pergunta aos judeus por que razão persistem ainda na culpa, embora saiba que é inútil lançar sementes à terra estéril e, por essa razão, o próprio Cristo lhe ordenou que pregasse o Evangelho aos gentios. Face a esta última alusão, a multidão indigna-se ainda mais, arrancando as vestes e sacudindo o pó. Arátor faz dois comentários distintos a este passo bíblico. Primeiramente, acusa os Judeus de insensatez, recordando que o arrancar das vestes mais não é do que o reconhecimento da culpa, pois também Adão, ao pecar, reconheceu a sua nudez; e lembra dois crimes hediondos da autoria do povo judaico: preferiu um ladrão, Barrabás, a Jesus Cristo, e apedrejou até à morte Estêvão, o primeiro mártir. Depois, debruçase sobre dois passos dos Actos relativos à conversão de S. Paulo, que aparentemente são contraditórios: no primeiro (Act. 9.7), diz-se que os companheiros de Paulo ouviram a voz de Deus; no segundo (Act. 22.9), que não a ouviram. O poeta resolve a questão, dizendo que, 
no primeiro caso, os companheiros do Apóstolo apenas ouviram um som difuso, não as palavras de Deus; no segundo, que não ouviram, pois não compreenderam a voz celeste.

Na secçáo 16 (vv. 992-1066; Act. 23.12-24; 24; e 25.1-12), contrariando os seus próprios hábitos de apresentar primeiro os factos e só depois extrair liçóes, Arátor principia a secção com uma arrojada invectiva contra os Judeus, pois que se preparavam para cometer o crime infando de atentar contra a vida de Paulo. Uma vez mais, tece algumas consideraçóes em torno de um número, o quarenta: o número de judeus que agora se junta para castigar o Apóstolo corresponde aos anos em que os Israelitas foram paternalmente protegidos por Deus no deserto, o que só aumenta a culpa dos infractores. A conspiração dos Judeus é, no entanto, denunciada pelo sobrinho de Paulo, e este é conduzido a Cesareia. Aí, Paulo defende-se das acusaçóes que lhe eram movidas por Tértulo, advogado dos judeus, declarando que nada tinha feito de contrário à Lei e que o caminho da fé, agora seguido e pregado, em nada contrariava os antigos ensinamentos. Paulo é retido por Félix até à chegada de Festo a Cesareia, e é este último governador que decide enviá-lo a Roma para ser julgado.

Na secçáo 17 (vv. 1067-1155; Act. 27.14-35), o navio que transportava Paulo é acometido por uma violentíssima tempestade que ameaça destruir a nau e a vida de toda a tripulação. O Apóstolo censura os companheiros por não terem seguido o seu conselho de não abandonar Creta, mas assegura-lhes a salvação, pois 
um anjo de Deus the deu tal garantia. A tempestade acalma-se imediatamente, os marinheiros avistam Malta e, antes de desembarcarem, Paulo exorta-os a partilharem consigo o pão. Arátor reflecte sobre a simbologia desta partilha do pão, figurado na velha Lei pelo cordeiro pascal, que permitiu aos Israelitas escapar incólumes aos perigos egípcios. Ora, Cristo, que é simultaneamente o cordeiro e o pão, foi a fonte de salvação em ambos os casos. Finalmente, o poeta afirma que também a Igreja está simbolizada no episódio bíblico pela imagem da lua.

Na secçáo 18 (vv. 1156-1205; Act. 28.1-6), em Malta, uma víbora salta de junto da fogueira onde Paulo se aquecia e morde-o, agarrando-se-lhe ao braço. Os malteses interpretam de imediato o sucedido como um sinal de que Paulo era culpado de um crime de derramamento de sangue. Entretanto, o Apóstolo arremessa a serpente para o fogo sem que o veneno lhe tenha provocado qualquer dano. Face a tal prodígio, invertem-se as opinióes acerca de Paulo, e os habitantes da ilha começam a dizer que ele é um deus. Arátor, à medida que narra os acontecimentos, vai tecendo comentários a propósito do reaparecimento da Diabo na figura da serpente e da insensatez dos que presenciaram o evento, quer quando acusaram o Apóstolo, quer quando o glorificaram.

Na secçáo 19 (vv. 1206-1250; Act. 28.7-16), Paulo demora-se três meses em Malta, curando o pai de Públio e muitos outros. Entretanto, chega a Primavera, o navio faz-se ao mar, e Paulo chega 
a Roma. É aqui que termina a glosa dos Actos dos apóstolos, pois a maior parte da última secção (vv. 1219-1250) constitui uma espécie de epílogo que remata o conjunto dos dois livros, relatando eventos que não se encontram nos Actos e deles extraindo as respectivas liçóes. Paulo escolhe, tal como Pedro, a cidade eterna, pois as cabeças da Igreja não poderiam eleger outro lugar que não a cabeça do mundo, a partir da qual a pregação seria mais eficiente. E, tal como outrora os dois irmãos Moisés e Aarão conduziram Israel ameaçado pelo Egipto, assim Pedro e Paulo guiaram a Igreja, assumindo-se como irmãos, não pela natureza, mas pelo martírio que lhes foi infligido por ordem de César no mesmo dia, volvido exactamente um ano.

Tal é, resumidamente, o conteúdo do segundo livro que a seguir apresentamos. Tratando-se de uma epopeia, alguns leitores, habituados a conjuntos de várias centenas de versos que constituem os cantos das epopeias clássicas, experimentarão, porventura, a estranheza e a novidade desta divisão do poema em pequenos quadros, as secçóes, com pouco mais de meia centena de versos cada. Mas esse aspecto é tão só um sinal dos tempos: não são apenas os heróis que são diferentes, também a forma de os apresentar difere. De resto, os tituli medievais que encabeçam cada secção (e que, na opiniáo unânime dos estudiosos, não são da autoria de Arátor) vieram acentuar ainda mais esta fragmentação da História apostólica, assim dividida em pequenos poemas ou, para citar Fontaine, "em 
medalhões de uma "Antologia» sagrada: uma espécie de «coroa dos Apóstolos»" ${ }^{4}$.

${ }^{49}$ Vd. Fontaine 1981 262, tradução nossa. 
(Página deixada propositadamente em branco) 


\section{HISTÓRIA APOSTÓLICA}

A gesta de S. Paulo 
(Página deixada propositadamente em branco) 


\section{EPÍSTOLA DO SUBDIÁCONO ARÁTOR A FLORIANO}


(Página deixada propositadamente em branco) 
O subdiácono Arátor saúda o santo e venerável senhor, espiritualmente instruído na graça de Cristo, abade Floriano ${ }^{1}$.

Ó Floriano, tu que já tens na origem do teu merecido nome a flor nascida de maduros pensamentos, pois, ainda na flor da idade, aos velhos deste liçóes ${ }^{2}$, pelas quais a vida ia preparando um caminho rumo ao Céu, acorre ao meu poema e estende-me com frequência

[a afável

mão do auxílio, pois vou tropeçando nestes pés!

${ }^{1}$ A identificação desta personalidade é simplesmente ignorada pela maioria dos críticos de Arátor. Floriano nasceu em Milão, no início do séc. VI, e morreu em 577 ou 578. As notícias acerca da sua vida são escassas e imprecisas, uma vez que são poucos os documentos que as podem confirmar: duas cartas do próprio dirigidas a S. Niceto (PL 72, col. 717-718), outras duas de Sto. Enódio (Ep. 15 e 16) e esta missiva de Arátor. Foi baptizado por Sto. Enódio, o seu primeiro mestre. Posteriormente, mudou-se para Arles, onde foi instruído por $S$. Cesário, junto de quem adquiriu um vasto saber e uma exímia instrução. De Arles retirou-se para a abadia de Romain-Moutier, onde abraçou a vida monástica, tendo sucedido a Teodato na direcção do mosteiro.

${ }^{2}$ Arátor usa o argumento cratílico para elogiar o seu destinatário. O próprio nome Floriano já pressagiava as flores da sua sabedoria e eloquência.

${ }^{3}$ Há várias leituras para este verso. Arátor pede auxílio para fazer face à grandiosidade da matéria, por onde vai caminhando. Por outro lado, apela a Floriano que o auxilie na métrica do poema, onde cada verso é composto por seis pés (hexâmetro dactílico). Por fim, pode ainda ler-se uma subtil referência à provecta idade do poeta. 
Num magro discurso, é certo, escrevemos, porém, pingues façanhas, e a gota corre na vastidão do pélago.

Embora guardes, entre pomposos livros em milhares de volumes, grandiosos assuntos, lê também outros mais singelos! E à maneira da natureza, que o Criador do mundo edificou, harmonize-se no teu estudo o excelso e o ínfimo!

A mesma terra que gerou tigres e alimentou leóes ofereceu os seios a formigas e a abelhas.

15 E, se reparares que o Soberano tudo reparte, verás que mereceram o engenho os dóceis; a força, os selvagens.

E a própria valentia, exausta, abandona o esforço constante e procura ter ocupaçóes várias. Ao soldado, habituado a pôr sobre os ombros a couraça, agrada entrar nu em recintos de ginásio.

E quem vence ferradas vanguardas e batalhóes também fere inofensivos animais com seus dardos. Portanto, retendo o passo e largando os velhos volumes, cede uns dias a esta obra que uma causa piedosa inspira. 
Epístola a Vigílio 
(Página deixada propositadamente em branco) 
O subdiácono Arátor saúda o santo, o mais bem-aventurado e apostólico senhor, e primeiro de todos os sacerdotes do mundo inteiro, papa Vigílio.

Ao ver as guerras acesas das undosas muralhas, eu fazia entấo parte do povo que os dardos temia ${ }^{1}$.

Ó liberdade do povo, Vigílio, papa santíssimo, tu vens soltar os grilhóes do cercado rebanho. Ao gládio são arrebatadas as ovelhas, e, ao teu apelo, solícito pastor, somos levados em piedosos ombros.

E não bastando ter, assim, esquivado do perigo o corpo, daí proveio ainda da minha alma a salvação.

Para a Igreja subo, náufrago do palácio abandonado; das pérfidas velas das águas mundanas me separo ${ }^{2}$.

Para as níveas cercas de Pedro, isentas de turbilhóes, me transfiro,

e gozo de um ancoradouro numa terra almejada.

Ele $^{3}$, que pisou caminho seco por entre as ondas, providenciou para nossas velas uma enseada na praia.

${ }^{1}$ Arátor alude ao cerco imposto a Roma por Vitiges em 537, no contexto da guerra entre os Bizantinos e os Ostrogodos.

${ }^{2}$ Este dístico constitui uma nota biográfica importante, pois permite confirmar a altura da entrada de Arátor ao serviço da Igreja: esta coincidiu com o início do papado de Vigílio (em 537), tendo Arátor abandonado a vida de corte (aula), em Ravena. Por outro lado, na expressão perfida uela, parece haver também uma alusão ao afastamento por parte do poeta da heresia professada pelos Godos, a perfidia Ariana.

${ }^{3}$ Tendo em conta o relato de Mateus (14.22-31), ille pode ser identificado com Pedro ou com Cristo. 
Réu poderei ser, se deixar de vos agradecer!

No reconhecimento de um só, os nove causaram desgosto ${ }^{4}$. Vivem os sentidos no ardor de celebrar os labores destes, por cuja voz a fé conquista os caminhos do orbe. Os Actos, que Lucas narrou, eu mesmo em verso os cantarei,

e, seguindo a história, entoarei um canto verdadeiro. Alternadamente, irei divulgando o que a palavra revela e o seu sentido místico, se algum o coração me conceder. Não é estranha a cadência métrica nos livros sagrados: foi a compasso lírico que os Salmos se compuseram; segundo consta, na língua original foram escritos em [hexâmetras melodias

o Cântico, as sentenças de Jeremias e ainda Job 5 . Ao oferendar-te, sublime pai, esta dádiva de amor, considera que saldo a dívida pelos teus serviços. Sob tua chefia, escolhem-me como recruta; sob teu [magistério, aprendo a doutrina: se algo vindo de meus lábios agrada, a glória será [do conselheiro.

${ }^{4}$ Alusão aos dez leprosos milagrosamente curados por Cristo, a quem apenas um foi grato (Lc. 17.17).

${ }^{5}$ Se sobre os Salmos e o Cântico dos Cânticos não há dúvidas de que foram escritos em verso, para o caso dos outros dois livros, Arátor terá seguido S. Jerónimo, que, nos prólogos a estas obras, confirma tal informação. 


\section{HistóRIA APOSTÓLICA, LIVRO SEGUNDO}


(Página deixada propositadamente em branco) 


\section{[Secção I]}

[Passo em que Saulo, também chamado Paulo, separado por advertência do Espirito Santo, chegou a Pafo, onde <Sérgio > Paulo era procônsul; e como havia um mago que se opunha à sua pregação, <Paulo > disse-lhe em alta voz que não mais veria a luz do sol, e imediatamente o procônsul Paulo abraçou a fé.]

O Espírito, impedindo que a lâmpada acesa pela palavra [radiante

brilhasse debaixo do alqueire", disse: "Separai Saulo para a obra da pregação." Pouco depois, o ilustre Pedro, a quem a palavra do Mestre concedeu todo o poder, consagrou [o viajante impondo-lhe as mãos. Partindo de Chipre e de Salamina, continuou rumo a Pafo, terra outrora rendida às paixóes, que, segundo se diz, permaneceu um antro de luxúria sacrílega e venerou os errantes alados com vergonhoso fervor ${ }^{2}$. Daí surgiu o auge dos seus feitos, porque uma graça maior acorreu às suas faltas ${ }^{3}$; e Paulo era já para Pafo um exemplo

${ }^{1}$ Cf. $M c .4 .21$, e $M t .5 .15:$ " [...] nem se acende a candeia para a colocar debaixo do alqueire, mas sim em cima do velador, e assim alumia a todos os que estão em casa”.

2 A associação de Pafo aos amores libidinosos e aos "cupidos" (os "errantes alados") é antiga. Floro (1.44) diz-nos que a ilha era consagrada à deusa do amor, Vénus: Insulam ueteribus diuitiis abundantem et ob hoc Veneri sacram Ptolemaeus regebat.

3 Cf. Rom. 5.20: "Onde, porém, abundou o pecado, superabundou a graça”. 
da possível remissão dos pecados. Que esplêndida ocasião de glória foi propiciada ao herói! Semeia castos primórdios na região da luxúria, e o campo dissoluto vai multiplicando os frutos do pudor. Após tais feitos, quem poderá desconhecer

15 e julgar difícil a virtude, pois parece que ela assim brotou nesse lugar imundo, para que nenhuma regiáo árida carecesse dos serviços apostólicos? No entanto, um mago iníquo tentou competir com ele em eloquência - desde sempre as adversidades abriram caminhos à virtude -, e o soldado da Igreja,

20 virando os dardos, disse: "A tua falsidade mostra que tu, filho de um tal pai, deves perecer. Na tua escuridáo, experimentarás a proximidade da morte e, até chegar a tua hora, está-te destinado não veres o sol nem observares as formas das coisas, cujo Criador tu negas existir." Então, nuvens se lhe cravaram

25 no rosto em escuras manchas, e a cor do seu negro coração veio à sua face. No caminho agora negado, procurava [ele um guia para poder ir em segurança, cujos passos pudesse seguir na caminhada, alguém que pudesse em piedade ajudá-lo. E, através do ar vazio, pôde tactear o caminho do erro. Paulo, o procônsul, imediatamente

30 reconheceu o brilho da fé; para ele as trevas do outro foi a causa de ver. Tais conversóes à salvação não te são estranhas, ó Paulo, bem sabes tu que a luz se ergue das trevas ${ }^{4}$. Todos estes exemplos revelam uma figura escondida, se nos aprouver tocar em coisas secretas com a mente vigilante:

35 Paulo, o mestre, começou com autoridade a realizar milagres a partir dos olhos, ele, cujo rosto resplandecia mais em brilho, após ter perdido a luz crescente do dia; assim, mais tarde, foi digno

${ }^{4}$ Efectivamente, também Paulo experimentou a cegueira (Act. 9.8-9) aquando da sua miraculosa conversão. 
de subjugar o homem malvado e levar de vencida o inimigo com o testemunho das trevas: embora cego, ele mereceu ver

[para sempre.

\section{[Secçáo II]}

[Passo em que S. Paulo, tendo entrado numa sinagoga em Antioquia, pediu silêncio com a mão; e aí falou de maneira semelhante quer sobre o êxodo do Egipto do povo israelita, através do mar, e sobre o tempo em que diversos milagres foram realizados no deserto, quer sobre o testemunho dado por João Baptista acerca de Jesus.]

Paulo visita a cidade cujo nome provém de Antíoco 5

e imediatamente se apressa a dirigir a palavra à multidão que se encontra na sinagoga e, pedindo silêncio com a mão direita, diz: "Sabeis com que ferocidade a terra do Egipto impôs um jugo aos nossos pais, a quem Deus resgatou dessas terras cruéis através de milagres. Entregando-lhe todo [o seu poder,

a natureza alterou o seu curso, quando uma vara afugentou o dorso do mar, e a vaga se perfilou afastada, sendo aprazível esse caminho poeirento, e o poder do mar foi subjugado e prostrado a seus pés; mas, voltando a ser profundo, haveria de causar o naufrágio dos culpados e, com ordens para

[mudar

as suas leis por diversas formas, para uns espalhou as areias, para outros fez subir as águas: um caminho para os justos, [vagas para os pecadores ${ }^{6}$.

${ }^{5}$ Cf. Plin. Nat. 6.47: Antiochus, Seleuci filius, [...] maluerat illam Antiochiam appellari.

${ }^{6}$ Sobre a passagem do mar Vermelho e a morte dos egípcios 
Quando a pedra fulminada lançou espuma das suas veias abertas, tendo jorrado uma corrente líquida do seu cume seco ${ }^{7}$

55 e engrossado o vau do rio, a antiga fonte não mostrou a sua velha natureza, nem ostentou o seu hábito, ao oferecer novos dons, pois a eterna lei obriga-a a seguir o que não lhe era inato, mostrando o que podia ser concedido de uma origem inusitada: alimentos do orvalho, bebida da rocha.

60 E para não serem poucos os milagres a fluírem de causas santas, as pedras jorram água, e transbordam de pães as nuvens, e em sólidos alimentos endurece a humidade do ar. E aquela multidão, há muito tempo de garganta seca, pelas águas frutíferas é saciada, e as nuvens lavradoras

65 um banquete propiciam: a chuva devoram, e é comido o aguaceiro 8 . Assim a invicta mão, assim a graça plena do Criador sabe alimentar os povos plangentes e transferir os abençoados coros para uma pátria melhor, para que o fruto do gracioso ventre possa florescer para as sementes da vida eterna.

$70 \mathrm{Na}$ verdade, gerado por Maria, sua mãe, da estirpe de David, veio Cristo, e todos os oráculos dos profetas anunciavam que ele havia de chegar como Deus encarnado e que o próprio

[Criador

entraria no seio virginal. Ponde a descoberto tudo o que os vossos sábados encobrem. Haveis de reconhecer os ensinamentos

75 da simbólica figura a brilharem no presépio do Sagrado Cordeiro, de cujo fogo os velhos profetas as suas previsóes hauriram,

perseguidores, cf. Ex. 14.21-30.

Cf. Ex. 15.23-25. Neste passo, descreve-se a miraculosa transformação da água, que se tornou potável quando Moisés lhe atirou um madeiro.

8 Referência à chuva e ao orvalho que Deus transformou em codornizes e maná, tal como aparece descrito no capítulo16 do Exodo. 
ao conceder-lhes dizer antes o que só mais tarde começou a ser. Poderoso na virtude, João Baptista proclamou:

'Eu não sou ele! Depois de mim virá um a quem eu não sou digno de tocar as sandálias dos pés, nem de desatar a ponta do humilde laço que une as excelsas solas'?."

Que bem cantou a voz de Paulo os preceitos do baptismo, misturando o antigo com o novo! A Epistola não cessa de o repetir, ao postular: "Resplandeceram nossos pais no mar Vermelho com o baptismo, encoberto na Lei pelo nome de Moisés, quando a pedra os seguia na sua caminhada; na verdade, a pedra era Cristo." ${ }^{10} \mathrm{O}$ que reclamas ainda, surda nação? Eis que ressoa nos teus livros: "Não demores a acreditar."11 Considera os milagres do mar, que sussurram os místicos dons que chegariam nos tempos da cruz, quando Jesus com seu sangue tingiu as águas, e de uma das feridas do lado fluiu o que daria os três dons da vida ${ }^{12}$ ! Aquele vermelho do mar foi pretexto de futuros eventos: assim o Criador a todos purificou, assim nos resgatou; essa cor do preço [da salvação] está no [turbilhão do mar, e milagres devidos ao lenho aparecem nos baixios.

\section{[Secção III]}

[Passo em que S. Paulo pregou novamente na mesma sinagoga sobre a paixão de Cristo, o sepulcro e a ressurreição, sob o testemunho de David; e como alguns acreditaram e os

${ }^{9}$ Cf. $L c .3 .16$.

${ }^{10}$ Cf. 1 Cor. $10.2-4$.

${ }^{11}$ Cf. Nm. 14.11.

${ }^{12}$ Um dos códices da História apostólica (Cantab. B. 14. 3. S. IX.) explicita os três dons referidos neste verso: Remissionem peccatorum, immaculatam conuersationem et post haec uitam aeternam. Vd. Mckinlay 195182. 
judeus o proibiram de falar, ele disse que iria pregar aos gentios; e converteram-se nesse mesmo lugar os que eram gentios.]

Paulo, desejando infundir com maior assiduidade os raios [de luz nas obscuras mentes, lembrou de novo estes factos na devida ordem: "Depois de Cristo, vestido com o manto da carne, ter realizado em toda a parte os sinais de Deus, tornando evidente que ele próprio 100 viera como salvação do mundo, a ímpia multidão, aos gritos, agitada pelo aguilhão da loucura, rogou a Pilatos que, no seu poder, o fizesse suspender e pregar numa cruz. Oh, mundana geração! Aquilo que nem todas as preces podem obter para quem o deseja, voluntariamente o concederam os dons de Cristo Salvador,

105 que por ti desceu dos Céus como preço da liberdade, reparando o que estava perdido e levantando o que jazia nos túmulos. Vê quão culpada permaneces diante do teu próprio rei! Para não [pereceres, ele mesmo desejou morrer. Mais ainda, após estes tristes eventos, requisitando um guarda e duplicando a sua impiedade,

110 quiseram selar o sepulcro e barrar o caminho preparado para a ressurreição do Senhor ${ }^{13}$. Oh, cega obstinação, julgando que o eterno é limitado pela lei mortal e que não pode, após a morte, devolver a si mesmo o corpo quem tantas vezes levanta o de outrem! Lembrai-vos das [palavras que soam

115 na voz da lira davídica: 'Não permitirás que o teu santo conheça a corrupçáao. ${ }^{14}$ Acaso podia tolerar demoras no pó da morte aquele que permanece vida, a quem Deus Criador ressuscita,

\footnotetext{
${ }^{13}$ Cf. Mt. 27.62-66.

${ }^{14}$ Cf. Sl. 16.10.
} 
sem nada sofrer da morte? Transgredindo o seu modo de vencer, foi por fim vencida a morte, que, depois de atingido o juiz, é obrigada a libertar os réus, e, despojada dos antigos espólios, cai por entre a sua própria guerra. E não devia ser retido quem viera os cativos soltar. Começou ali a morrer na presença da vida o último quinhão do Averno, e quem antes [exercera o domínio sobre todas as coisas pereceu ali mesmo. E, três dias passados, aproximou-se do caminho da luz por ele edificado, no qual a natureza ressuscita por completo no seu Senhor; bem vedes que, só com [a vossa lei, se não podem desprender as mortes. Procurai aquele por cujo sangue nos reunimos purificados no Reino do Senhor, onde temos já um quinhão pelo penhor da carne, que Deus quis tomar sobre sil" Tais ensinamentos logo concedem alguns homens à Igreja. Proibiram-no de continuar a proferir as santas palavras. Oh, sempre fútil, oh, Judeia para ti mesma estéril, que afastas as sementes por não poderes suportar os frutos! A estes, com palavras de mestre, diz Paulo: "Era a vós, era a vós que conviria reconhecer tais factos, mas esta luz será para outros, pois as Escrituras proclamam: 'Designei-te para seres luz para os gentios, nos confins do mundo' ${ }^{15}$." Ficaram estupefactas as turbas de gentios e, buscando a fonte, desejaram assumir a honra da novidade prometida e, regenerados pela água mãe, mereceram renascer. Perante tamanho dom, acho conveniente, pelo interesse do passo, extrair a verdade daquela história que afirma que um dia, quando Rebeca dois povos e duas naçóes carregava no seu ventre, e naqueles apertados muros multidóes encerrava,

${ }^{15}$ Cf. Is. 42.6, e 49.6. 
145 consultando o Tonante e pedindo-lhe com o coração suplicante, mereceu de Deus a resposta: "Entre eles", disse, "o primeiro permanecerá como inferior e súbdito, e o mais velho servirá o mais novo, e o mais jovem obterá a glória da palma." ${ }^{16}$ Tudo quanto a fértil parturiente carregou em seu ventre

150 existe no seio da Igreja; e representa a segunda figura a afluência dos gentios, que crescem num ventre onde eram já vencedores ${ }^{17}$. Isto é necessário recordá-lo agora e proclamá-lo com zeloso fervor, para podermos servir aquele por cujo afecto tivemos a sorte de sermos chamados antes

155 de nascermos, e antes do tempo nos oferece seus dons.

\section{[Seç̧ão IV]}

[Passo em que S. Paulo curou, em Listra, um coxo que, desde o ventre materno, nunca andara e começava a ter fé graças à sua pregação; quiseram oferecer sacrifícios a Paulo, mas este, falando-lhes das antigas superstiçóes que tinham, advertiu-os de que, agora, deviam acreditar apenas em Cristo.]

E agora, dirigindo seus passos para as terras da Licaónia, Paulo aproxima-se de Listra. Havia, então, nessa cidade, um coxo, nascido com tal castigo por companhia, não sabendo desde o ventre como dirigir seus passos; parte do doente começara a morrer 160 em seus membros logo à nascença. Tendo notícia do ensinamento [de Paulo, por cuja instrução as piedosas mentes se dirigem aos Céus, quis imediatamente seguir o divino. Como jazias tu, ó coxo,

${ }^{16}$ Cf. Gn. 25.23.

17 Arátor vê estas duas figuras veterotestamentárias como tipologias: Jacob prefigura a Igreja, tal como Esaú simboliza a Judeia. 
prestes a trilhar pela primeira vez estes caminhos; almejas [pela razão o Céu, embora te não tenhas ainda movido na terra, e, apesar dos

[passos negados, podes ir mais além! Paulo, vendo que dele a fé se apoderara no mais fundo do coraçáo e que agora o amor do fiel coxo na palavra de Deus permanecia, disse mais alto estas palavras: "Levanta-te imediatamente e apoia-te direito sobre teus pés!" Realizou-se a cura prescrita, e, pelo seu caminho novo, avança a pessoa velha e, num contínuo movimento, marca o solo por toda a parte e, tentando por todo o lado correr, teme muita vez o caminho desconhecido o velho que, só

[agora ao caminhar, se ergueu da fraqueza de muitos anos. Quando isto viu, a multidáo gritou e invocou Paulo como um deus e com grinaldas o ornou, enquanto a vítima, um touro selvagem, foi avançando para o sacrifício. Perante estes factos, ele rasgou sua túnica, rapidamente [travando os homens com um claro argumento: "Por que razão, pergunto, nos ofereceis tais cerimónias, sendo evidente que nos oprime a fragilidade do corpo, segundo a lei da terra? Ímpio foi outrora o respeito pela religião, quando os seus artífices temeram divindades de metal fundido dedicando templos aos deuses cinzelados da rocha. Nessa altura, talvez fosse permitido rebanhos inocentes sacrificar e suas entranhas quentes consultar e nas vísceras do animal moribundo buscar o oráculo.

Agora, abandonados os vãos altares, alegremo-nos

em obedecer ao eterno Deus, que as sementes da vida forneceu e os campos preparou para colheitas variadas;

por cuja ordem do grão moribundo se ergue a seara 
em fartas espigas, e produz o sarmento cortado

190 uvas em abundância, da sua ferida geradas; com ele a reger o céu, sucedem as chuvas aos sóis, as estaçóes às estaçóes, e enquanto estas, fugitivas, umas sobre as outras vão correndo, a constância do ano errante permanece. Aprendei agora a aclamar o filho da Virgem santa,

195 verdadeiro Deus na terra, e não dirijais funestas preces ao lanígero rebanho, vós que sois libertados pelo Cordeiro Único, que resgata o mundo purificado pelo seu sangue!" Foi com estas palavras a fé ensinada; mas o cuidado do corpo num duplo efeito resultou, e uma só cura faz ecoar 200 uma dúplice figura, pois em todo o mar deste mundo dois são os povos da Igreja, guiados pelas palavras de dois homens, a quem a faina enche duas barcas. E os pés de ambos os coxos à espécie humana ensinaram estas coisas comparadas, e através deles uma imagem se ergue 205 comum aos dois povos, conservando tudo o que lhes é singular. Aquele a quem Pedro concedeu levantar-se pelos seus antigos pés era da porta vizinho; desse lugar vem a circuncidada naçáo ${ }^{18}$, a quem os Salmos, a Lei e os Profetas vaticinaram o dia de Cristo. Aquele que Paulo levantou do cháo, 210 jazendo em terra distante, jamais se havia sentado perto do santuário do templo, porque, tendo pelos gentios [principiado, com a boca piedosa começou a revelar os trilhos

${ }^{18} \mathrm{O}$ episódio da cura milagrosa do coxo por Pedro aparece em Act. 3.1-8 e é assunto explorado na sétima secção do primeiro livro (vv. 244-292). Aí, destaca-se a simbologia da cura deste coxo que, por ter o costume de se sentar junto à Porta Formosa do Templo, personifica a conversáo dos Judeus ao Cristianismo. Ora, esse facto vai servir agora ao poeta para estabelecer o paralelo com o coxo sarado por Paulo, que simboliza a adesão dos gentios à fé cristá. 
da firme sabedoria às ignaras multidóes e a curar o povo que a antiga voz de Deus ignorara. Assim, quando os dois coxos caminham, erguem toda uma nação, e o caminho de uma pessoa assinala a salvação de um povo; a glória destas proezas fez com que Paulo, pela ordem, fosse segundo em relação a Pedro, que, naqueles alicerces, permanece o arquitecto.

Mas, para recordarmos os méritos do Criador em relação a tudo, há também aqueles cegos que, com as multidóes a apressarem-se

[por toda a parte, em uníssono disseram ao Senhor: "Excelso filho de David, concede-nos sair das pesadas trevas, concede-nos vislumbrar a luz que ainda não conhecemos!"19 Então, aquela mão da cura sempre amiga trouxe súbito brilho, e a noite abandonou seus olhos, e o dia exilado iluminou suas órbitas, e a visão, regressando, temeu os crepúsculos inesperados. São estes manifestamente os dois povos a quem a natureza, culpada da sua origem, cegou. A clemência de Jesus, quando inaugurou o caminho, ao querer habitar os tempos

[da carne,

renovou a partir da luz, purificando a figura

pelos pecados delineada, e logo brilhou a intacta imagem que mereceu possuir o sentido de Deus. Das partes à cabeça unidas a mais alta é os olhos; como dádivas os fez Cristo, que é do mundo cabeça e esplendor. No fim estão os pés, de todas as partes a mais baixa; é a estes que o zelo da voz apostólica sara neste baluarte, pois formosos são chamados os passos que a todas as terras levam a paz $^{20}$. Emanou das trevas a luz graças aos dons do Mestre.

${ }^{19}$ Cf. Mt. 9.27-30.

${ }^{20}$ Cf. Is. 52.7: "Que formosos são, sobre os montes, os pés do mensageiro que anuncia a paz". 
Estes, a quem foi entregue o desígnio da palavra, determinam [a marcha, 240 para que a segunda medicina se robusteça na bondade da primeira, e pouco a pouco se possa espalhar por todo o orbe a salvação.

\section{[Secçáo V]}

[Passo em que S. Paulo, depois de numerosas disputas na sua pregação com os judeus baptizados, procurou resolver a controvérsia de os gentios não poderem receber o baptismo antes de serem circuncidados. Por essa razão, foi aconselhar-se a Jerusalém, e S. Pedro foi do parecer que tal não fosse imposto aos gentios, opinião seguida por todos os apóstolos.]

Já as violentas fúrias dos homens Paulo dominara. Com a fé a navegar, novas perfídias provenientes da nuvem judaica arremessaram súbitas tempestades: o baptismo a ninguém

245 podia ser dado, antes de chegar a circuncisão da carne, de acordo com a lei de Deus. Ó dura nação, porque apelas ainda ao cutelo de pedra? Este foi apenas a sombra da figura, a sua forma não devia permanecer. Deixa a aparência, tu que agora vês a realidade! Pela boca de Cristo avançou

250 a vida que permanece, e a todos quantos chegam ele ordena que renasçam na fonte ${ }^{21}$. Porque hão-de amputar os membros e livrar-se de uma parte, podendo o todo salvar? Não consintas que o poder da Boa Nova pelo velho costume seja esmagado, nem que os luzeiros curvados sejam postos atrás, depois de um caminho mais

[justo a todos

255 conduzir, iluminando o mundo, desbastados que foram os espinhos.

${ }^{21}$ Cf. Jo. 3.5: "Em verdade, em verdade te digo: quem não nascer da água e do espírito não pode entrar no Reino de Deus". 
Perante tấo duvidosa questão, Paulo dirigiu-se aos locais da cidade onde brilham as memórias da cruz, e revisitou os sagrados mestres da autoridade apostólica, a quem relatou em pessoa tudo quanto foi realizado. Pedro, cuja maior preocupação é aumentar os rebanhos a si confiados, a todos chamando aos ricos pastos sob a sua chefia, deixa sair dos lábios estas palavras: "Vedes que o Deus Eterno em nós cumpriu o que foi lembrado nos séculos antigos, e que os profetas predisseram ao povo pela sua dócil boca; como redentor, ele escolheu ser para todos a salvação, consentindo não excluir ninguém no preço pelo qual a vida regressa. Ele ordenou-me que aos gentios mostrasse este caminho aberto. De que serve adiar e atrasar seus desejos, ou de que adianta misturar com a nova luz estes enigmas? Aos que a graça purifica, nenhuma lei os impede de virem. A fé expedita é a fonte do amor celeste; é a ela que Cristo adopta, é ela que ele toma por sua; quem dela merecer usufruir já está circuncidado e, por direito, renasce das águas." Determinaram seguir seu pastor. Apraz-lhes, então, que alguns [irmãos o acompanhem e libertem os gentios com uma carta amiga, para tal jugo não mais lhes pesar; mas deviam ter certos cuidados: não adorar imagens, cujas libaçôes deveriam sempre amaldiçoar; não comer animais asfixiados, que são manchados pelo próprio sangue; e não serem esmagados pelo impuro desejo, mais selvagem do que o inimigo, aqueles a quem a luz purifica

[no baptismo.

E para serem mais transparentes as liçóes desta figura e a razão pela qual a imagem que primeiro se tinha imposto entretanto se dissipou, importa recordar o início. Deus disse: "Abraão, 
para agora estabeleceres, na tua carne, a minha eterna aliança

285 para ti e para a tua descendência, circuncida voluntariamente com a faca o prepúcio e estabelece com isto os pactos celestes." ${ }^{22}$ Sondemos o poder secreto, vejamos nessa ferida a aliança de Deus, testamentos que ele, na sua prudência, ocultou, para confraternização do Olimpo com a terra;

290 aprendera a jurar-lhos o servo que primeiro encontrou Rebeca junto à água que manava da fonte da Igreja ${ }^{23}$. Essa parte dissoluta do corpo, onde foi circuncidado Abraão, contém a luxúria e, como acessório do vício, rege-se pela lei da natureza. Ele próprio, que estava para ser o pai

295 da semente de onde brotaria para a vida a salvação do mundo, aniquilou a parte que o pecado sobrecarrega; depois de [amputar o desejo, ostentou virginal conduta: na verdade, esta descendência concebeu o divino caminho. A partir daí, foi destinada a um parto novo Santa Maria, que, embora privada de homem,

300 foi mãe, e o filho de Deus do ventre de uma virgem surgiu, e o Mediador foi em tudo um homem completo, de um lado elevando o terrestre, e do outro oferecendo o celeste. Por conseguinte, cessa a velha figura com o nascimento de Cristo: a sua beleza renova toda a Lei e, com a abolição do cutelo, 305 o Espírito Ardente circuncida o coração nas ondas, para não infligirem chagas aos seus membros os que se curam [nas águas.

\footnotetext{
${ }^{22}$ Cf. Gn. 17.9-11.

${ }^{23}$ Cf. Gn. 24.1-16.
} 


\section{[Secção VI]}

[Passo em que S. Paulo foi impedido pelo Espirito Santo de pregar na Ásia. Aquele, atravessando também a Misia, chegou à Macedónia, pois numa visão avistara um macedónio em pé, a pedir-lhe que se dignasse antes dirigir-se para a Macedónia.]

Entretanto, Paulo, incapaz de se dar ao descanso pelas
[preocupaçóes, ensina pelo mundo e com as enxadas da palavra vai cavando todos os campos e obriga a seara da fé a amarelecer, derretendo a geada dos erros. O Espírito Criador proíbe-o de oferecer isto à Ásia, e nem a Mísia, de terras férteis, pôde, nessa altura, receber as sementes desta salvação; estéril, apesar do solo fecundo. É que um homem macedónio, visto em sonhos, disse isto: "Tem piedade, imploramos-te! Considera merecedora a costa da Ilíria!" Oh, quanto providencia a graça inesperada! Os que têm já uma hora marcada são inflamados pelo amor imprevisto. Assim, afastada a noite, o grandiloquente altera o percurso, a Macedónia esfomeada alimenta-se com o fruto da palavra e, graças aos dons do sono, mereceu compreender o idioma da salvação. Uma dúvida frequente ecoa: se, pleno de generosidade abundante, o Omnipotente proclama "Eu não vim para destruir o mundo, mas antes para o salvar" ${ }^{24}$, que motivo determina que isto seja [a uns negado e a outros concedido, pois a abundante misericórdia de Jesus a todos deseja prestar auxílio por igual?

Nesta questáo, dispomos de uma enorme abundância de exemplos, e a sua leitura dá-nos o ensinamento de uma figura complexa,

${ }^{24}$ Cf. Lc. 9.56. 
sobre a qual direi algo: de acordo com o relato de Lucas, alguém dentre a multidão pedia para ir como discípulo de Cristo, 330 mas este proibiu-o de o seguir, para depois chamar um outro calado por natureza ${ }^{25}$. O Mestre, que purifica o interior, conhece os coraçóes que podem num momento receber a palavra e os [que o iníquo pecado ainda obstrui por dentro, para que a doutrina, chegando com [eficiência, possa aí cumprir o seu dever; ele mesmo o afirma: "Não [comecem

335 os cães a violentar o sagrado, nem os porcos, prostrados no lodo, virem suas imundícies contra as pérolas.”26 Outra questão igualmente difícil subsiste no poema, mas àqueles para quem todos os ensinamentos da fonte antiga foram evidentes, é simples fazer entender as gotas fornecidas pela minha

[humilde boca:

340 o famoso livro do Exodo enumera os trajes do pontífice sagrado $^{27}$; pela sua veste, ele pode certamente resplandecer e compor o hábito do seu ofício com um aparato brilhante. Assim ornamentado, ele ergue-se no meio dos altares, e entre tais esplendores contam-se, numa envolvência harmoniosa,

345 os paramentos na coxa, com os quais pode cobrir as partes íntimas, ao dirigir-se para o templo, como sacerdote, esforçando-se por abordar castamente os mistérios, com os rins apertados.

${ }^{25}$ Cf. $L c .9 .57-59$, e $M t .8 .19-22$.

${ }^{26}$ Cf. Mt. 7.6, e 2 Petr. 2.22.

${ }^{27}$ As vestes sacerdotais de Aaráo aparecem descritas no capítulo 28 do Exodo. No capítulo seguinte, Deus estabelece os rituais dos sacrifícios, fazendo nova referência aos trajes de Aarão e dos seus descendentes, os únicos autorizados a presidir aos sacrifícios. Portanto, é nestes dois capítulos que Arátor se inspira para os versos subsequentes (341-353). 
A antiga lei estabeleceu esta regra e prescreveu que fossem então escondidos e bem presos esses membros que o escuro desejo controla, quando ele se dirige para oferecer libaçôes a Deus, mas deixou-os

[livres

para a uniáo conjugal após os ritos sagrados, para que um uso [mais moderado não fosse obstáculo ao trabalho da prole, e o amor do casamento não arrefecesse por desmazelo do marido, pois a descendência eleita, que cumpria esse ritual, nunca admitiria quaisquer homens de outra estirpe $\mathrm{e}^{28}$ onde, por um nome antigo, perdura a honra do sacerdócio, renovando ao longo dos [tempos uma prole digna de ser santificada ${ }^{29}$. Em vez de criar o que deve ser substituído, a sagrada fé da Igreja prescreve agora que os seus pontífices sejam castos para sempre e, previdente, procura em toda a tribo aqueles que pode convenientemente aprovar, e esses não serão sucessores pelo sangue, mas antes pelo mérito. Todavia, aquela figura, sem a qual nem uma só letra velha subsistiria, finalmente perdura melhor através desta inovação e, voltando de novo, [póe fim à regra da alternância, talvez para que o sacerdote não escolha procriar antes de ver as multidóes de coração aberto

a aproximarem-se e a elas se dedicar e, quando vir a paixáo e a fome de aprender, que ele solte mais largamente a voz, para nem um só partir sem comer. Na verdade, também Paulo

${ }^{28}$ Isto é, ninguém podia oferecer sacrifícios a Deus a não ser Aaráo ou os seus descendentes, tal como aparece explicitado em Nm. 7.6: "Isto deve servir de memorial para os filhos de Israel, a fim de que nenhum profano, estranho à linhagem de Aarão, se intrometa a oferecer o incenso diante do Senhor".

${ }^{29}$ Pertencendo Aarão à tribo de Levi, daí decorre que só os Levitas poderiam ser sacerdotes. 
afirmou que se podia conceber descendência da semente da [palavra, ao dizer

370 com frequência "filhinhos meus." ${ }^{30}$ Apraz, então, que a eloquência [procriadora seja por momentos refreada e que o mestre vá repartindo o seu entusiasmo, soltando, conforme o tempo, as forças do [seu talento ou mantendo-as presas, e reservando as coisas santas para os puros, não vão os infiéis esmagar com seus pés a pregação.

375 A lei divina proíbe lamentaçóes a este propósito; que o castigo [da sua veia ${ }^{31}$ impute isto às culpas de Adão. De facto, o que pode uma [descendência, culpada pela boca de seus pais, pedir com justiça para si, se o benigno Criador nấo quiser dar tudo quanto o erro imprudente levou com um nascimento corrupto? O único caminho de salvaçáo 380 será a afeiçấo do misericordioso; a sua compaixão está sempre isenta de condiçóes; oferecendo o que não deve, Cristo, na sua piedade, apressa os dons para alguns e, na sua justiça, atrasa-os para outros ${ }^{32}$.

\section{[Secção VII]}

[Passo em que S. Paulo expulsou o espirito de Piton do corpo de uma jovem pitonisa, que clamava que se devia acreditar em Paulo, pois era servo do Deus altíssimo. Por esta razão, foi maltratado e, juntamente com Silas, metido na prisão, onde, estando eles de noite a entoar salmos, as cadeias de todos

${ }^{30}$ Vd. Gal. 4.19.

${ }^{31}$ Isto é, a humanidade, descendente de Adão e portadora do pecado original por ele cometido.

${ }^{32} \mathrm{Ou}$ seja, Deus, na sua misericórdia, entendeu que Paulo devia levar a palavra da salvação aos Macedónios e não aos Asiáticos. 
se desprenderam; e, como o carcereiro se quisesse matar, ele impediu-o, tendo-o depois baptizado com todos os seus.]

Quando o caminho do mestre percorria as famosas muralhas de Filipos, em terras da Macedónia, uma jovem enfurecida sob o estímulo de Píton disse: "Sabei que Paulo é servo do Deus Eterno.” Uma profissão verdadeira faz-se ouvir de uma testemunha mentirosa, e o seu pérfido autor teve palavra fidedigna; mas não se pode receber como honra aquilo que o medo obriga a proferir, nem o temor, desprovido de amor, persevera no espírito. Lamentando Paulo que os coraçóes estivessem oprimidos pelo negro demónio e não podendo consentir ao profano abrir caminhos divinos, disse: "Desaparece e livra-te de tentares estas coisas por mais tempo!" Sem retardar o cumprimento da ordem, vai-se embora o inimigo, e o maléfico possuidor deixa a casa vazia, e a mulher, curada do perigo que se pôs em fuga, calou-se com o louvor ao homem. Ela, que acabou o que começara e em silêncio melhor ensinou que dizia a verdade ${ }^{33}$, tirava proveito dos presentes da multidão para os seus senhores que, possuídos

[pela sombria loucura de que ela se libertara, gritam aos ouvidos do povo insolente e tumultuoso que era pregada uma religiāo contrária à religião romana, que novos rituais corriam mundo e que os velhos deuses haviam caído. Então, a multidão de imediato se aglomerou junto ao cárcere, flagelou com incontáveis vergastadas o corpo de Paulo, encarcerou-o com o companheiro Silas em recônditos lugares, e prenderam os pés de ambos, enfiados em madeira oca, com ditosas correntes. Oh, que lugar feliz pela desgraça! Para ele resplandeciam

${ }^{33}$ Isto é, que "Paulo era servo de Deus". 
luzes brilhantes em vez de trevas, nele a antiga noite deu lugar ao dia perene! Transformado no níveo palácio

410 da Igreja e a todos ofertando agora os dons da salvação, que bom era o cárcere! Por toda a cidade havia grande correria para se ser o primeiro a chegar ao renovado edifício, ou para [depositar beijos nas ombreiras das portas e ser abençoado ao tocar na parte do cilindro. Já o sono nocturno começara a serpentear pelos corpos

415 cansados, quando a terra, imitando uma catástrofe, se agitou, sacudida nas suas entranhas, e o chão, movendo-se, oscilou, abrindo os ferrolhos, e o flagelo, escravo da terra, assiste aqueles que entoavam hinos. Ah! Fé que nada pode superar, quanto revelas! Chegando o perigo,

420 esvai-se o castigo, e crescem, num duplo medo, as ameaças de que a tormenta arrasasse o lugar. Sacudindo seus membros do alto leito, quando viu os antros da morte vazios, o guarda, tremendo, quis levar a mão com a ponta descoberta da espada à garganta. Mas não lhe era permitido morrer

425 tendo como testemunha Paulo, por cuja consolação reencontrou a vida e mereceu ser libertado do seu próprio cárcere. Descendo a sua casa, providencia remédios para as feridas sagradas e, tendo voltado a si, prepara-lhes água límpida, ele que havia de tocar na água celeste. De facto, Paulo, que gosta 430 de trespassar os corações com a salvação, lavou-os a todos [juntos na água corrente; e para aquele, a quem antes se revelara a graça da luz celeste para não se matar, brotou, depois de renascer, uma nova vida. Outrora, Eva, prestes a enganar o marido, foi atraiçoada com palavras aduladoras; agora, o ímprobo demónio, que então

435 fazia mover os lábios da rapariga, procurando de novo para seus crimes 
o mesmo sexo do qual ele foi o salteador, era o instigador do pecado, ao prever, para muitos, o que havia de suceder. Mas o Apóstolo, já melhor que Adáo, que havia sido um homem da terra ${ }^{34}$, vislumbrando naquela imagem um sinal celeste, náo tomou por verdadeiras [tais palavras]. $\mathrm{Na}$ verdade, o que vem do inimigo engana tanto que devemos

[todos recear ouvir tal abominação, para não sermos corrompidos pelo mel de um amargo engano ${ }^{35}$, mesmo se diz a verdade quem nos

[serve a mentira.

\section{[Secçáo VIII]}

[Passo em que S. Paulo argumentou com os filósofos epicuristas e estóicos em Atenas, onde opovo lhe chamou "semeador de palavras"; e depois dissertou sobre variados assuntos, referindo um altar que tinha visto; Dionisio Areopagita foi o primeiro a abraçar a fé, juntamente com alguns outros.]

Paulo entra em Atenas, célebre pelo talento e pela eloquência, e, num discurso abrasador, arrasa a cidade intumescida por ferozes querelas; admirada de que ele falasse com modos tâo harmoniosos, a multidão diz: "De que costas saiu este semeador de palavras ${ }^{36}$ ?" O povo, sem saber, chama a Paulo

${ }^{34}$ A expressão homo terrenus relaciona-se com a própria etimologia do nome do primeiro homem. Tal como se pode verificar em Gen. 2.7 e 3.19, o nome Adão está relacionado com 'adamah, que significa "solo" ou "barro".

${ }^{35}$ Trata-se de uma lição que encontramos, por exemplo, em Ovídio, quando este afirma que "ímpios venenos se ocultam debaixo do doce mel” (Am. 1.8.101, tradução nossa).

${ }^{36}$ A expressão usada por Arátor, uerborum sator, traduz muito melhor o original grego, spermológos, do que o termo que aparece na Vulgata, seminiuerbius, já que este último vocábulo tem um sentido muito mais depreciativo. 
portador das sementes e, dizendo a verdade, usufrui de um erro que a ensina. Na verdade, caminha pela terra e cultiva-a

450 este fecundo viajante, cujo trabalho a todos se destina, para que o campo divino vá aumentando e o espírito humano, purificado, produza fruto, e não se suje com as ervas do joio quem deve ostentar searas. A invejosa turba obriga-o a acompanhá-la até aos magistrados, a quem declarou, em pé:

455 "Filhos de Cécrope ${ }^{37}$, a quem a tradição celebra pelo hábil discurso florescente nos seus ginásios, onde o profundo amor pela novidade sacrílega governa, verificámos que erigistes um altar ao deus desconhecido, que formou os astros, que concedeu o mar e a terra, a quem a vida tem por autor, 460 para nos podermos mover, de cuja chama nos animamos, de quem somos a imagem, sobre o qual cantaram os poetas que aí radica a espécie humana ${ }^{38}$, aquele que eu apregoo: 'Tudo consagrou pela sua palavra. ${ }^{39}$ Porque chamais, então, divinas a estas imagens que fazeis e, livres de qualquer receio, tomais 465 por auxílio celeste o que a terra gerou? A essência do metal jaz profunda nas vísceras da terra e, daí extraída, recebe o contributo do talento do artesáo, quer daí provenham deuses para os templos ou potes para o lar; a arte que fabricou [os deuses é a origem do seu próprio temor, pois ninguém pode restringir

${ }^{37}$ Os Atenienses são chamados "Cecrópidas", ou "fillhos de Cécrope", pois, segundo a lenda, foi este o primeiro rei de Atenas (vd., v.g., Suda, s.v. Kékrops [1272]). Pela mesma razão, também os Romanos são frequentemente apelidados Romulidas (vd., v.g., Verg. Aen. 8.638).

${ }^{38} \mathrm{O}$ Apóstolo refere-se concretamente ao poeta Arato que, no verso 5 do primeiro livro dos Fenómenos, afirma: «Somos também da sua raça». Cf. também Act. 17.28.

${ }^{39}$ Cf. 1 Tim. 4.4-5: "Porque tudo o que Deus criou é bom [...], pois é santificado pela palavra de Deus e pela oração". 
o Senhor, que está em toda a parte, e reduzi-lo a pequenas imagens, sendo o conteúdo menor do que o tamanho do continente. No ouro está a sua matéria; o artífice do universo não admite práticas de simulação àqueles que ele mesmo criou. Que duros crimes vós expiais! Quão louca se há-de reconhecer a si mesma a vossa sabedoria no Dia do Juízo, quando Cristo ordenar que todos os corpos se levantem, e os tormentos não hão-de ter fim, de tal sorte que o fogo supliciará os culpados, preservando os

[que vai consumindo! Assim, é junto de Deus que a carne expia os actos carnais, e as faltas contra ele cometidas são pesadas pelo Vingador através dessa [carne], na qual desejou padecer, ao expirar, e que ele, querendo reviver depois do Tártaro, restituiu aos Céus, imune à morte.” Tais palavras chamam muitos para os dons. Por si mesmo, Dionísio é o primeiro na cidadela desse país a juntar novos benefícios

[à sua dignidade e, tendo abraçado a fé, começa, deste modo, a ser amigo do saber. Ó Paulo, lobo rapace! A bênção de Jacob permitiu-te 485 ostentar esse nome ${ }^{40}$. $\mathrm{O}$ que pode agora restar no mundo que tu não arrastes com teus lábios, depois de ter recuado a grega sagacidade e teres vencido Atenas, invencível em matéria de doutrina? Por que motivo só o epicurista e o estóico lhe movem ímpias guerras? Impóe-se revelar em nome de que princípios se formaram muitos grupos de sectários. Ambos escolheram seguir a felicidade da vida, que aquele considera estar no corpo, e este cultiva-a na virtude da alma. Também a intervenção de Paulo fornece preceitos para uma vida piedosa. Unindo assim as

[duas teses,

${ }^{40}$ Cf. Gn. 49.27: “Benjamim é um lobo rapace”. Uma vez que Paulo pertencia à tribo de Benjamim, Arátor considera que a bênção de Jacob também se estende ao Apóstolo. 
495 aqueles soltaram mais as suas línguas, falando alternadamente. O homem completo existe através da reunião das partes do corpo e da alma, mas agora, seguindo teses contrárias nas [suas posiçóes, ambos querem o que nenhum dos dois tem. Mas aquele vaso [cheio de luz submete ambos [corpo e alma] a Deus, ao exclamar "Vejo quão hostil 500 é a carne ao meu espírito" ${ }^{41}$, e beneficamente recomeça dizendo que não acontece por vontade própria o que a graça concede $\mathrm{e}^{42}$. Frequentemos este caminho, porque Cristo é a vida, e ele próprio se chama caminho a si mesmo ${ }^{43}$, de molde a chegarmos a ele por ele. E, para que a lanterna sagrada não retardasse seus passos,

505 foi oferecido um arauto que mostra ao mundo os trilhos da fé.

\section{[Secção IX]}

[Passo em que S. Paulo, chegando a Corinto, encontrou um pregador chamado Áquila, em cuja casa se hospedou, trabalhando com ele na arte de fazer tendas, na qual eram eximios, isto é, no fabrico de tabernáculos; ai Cristo aconselhou-o a não negligenciar a pregação, e todos nesse lugar abraçaram a fé.]

Com a sua partida, Paulo tinha já deixado o povo ático dominado pelas palavras sagradas e, dirigindo-se às vizinhas

${ }^{41}$ Cf. Gal. 5.17: "Porque os desejos da carne são opostos aos do espírito, e estes aos da carne, pois são contrários uns aos outros". A hostilidade dos partidários das duas correntes filosóficas (vv. 489-498) encontra plena resposta neste passo de S. Paulo, ao afirmar que a felicidade não se pode situar apenas ao nível da carne, como postulavam os epicuristas, ou exclusivamente ao nível do espírito, como afirmavam os estóicos.

${ }^{42}$ Cf. Rom. 11.6, 9.16, e Tit. 3.5.

${ }^{43}$ Cf. Jo. 14.6: "Eu sou o caminho, a verdade e a vida". 
muralhas de Corinto dos dois mares ${ }^{44}$, encontrou uma populosa [cidade

que, embora tocasse as ondas de dois pélagos opostos, estava sedenta das águas perpétuas. Nesse lugar, Áquila de Ponto era, então, afamado mestre, homem possuidor de inúmeros dons dignos de louvor, a cuja hospitalidade amiga Paulo se entregou, tendo-se dignado entrar numa casa aliada pelo amor do ofício; de facto, eram ambos fabricantes de tendas e sobressaíam no zelo do trabalho e na ciência da Lei.

Cristo disse: "Ensina agora, Paulo! Ninguém se te opóe, enquanto eu te acompanhar. Vês que multidáo eu tenho nessas muralhas. Persiste na pregação, eu te fortaleço o coração!" Tais palavras ensinam que ninguém se pode jamais queixar da demora de um dom que a clemência de Cristo concede de graça. Para que, porventura, a figura encoberta não se esconda no ambíguo, cantarei por que razão ela foi dada. As Sagradas Escrituras anunciam que de um nome se extraem muitas vezes os argumentos e se produzem os maiores ensinamentos. É, portanto, vantajoso [investigar mais profundamente esse amável anfitriáo que se junta a Paulo, sendo já companheiro de ofício, sob cuja imagem estará o motivo de ele possuir tal nome, ou investigar de que honra é ele digno, agradando também por este aspecto. O temperamento em si mesmo seguro da águia indicia o que a imagem abarca. Com efeito, a ave, débil pela idade e já com a vista distorcida pela velhice, estende-se ao sol que expele chamas, aquece no seu fogo as penas entorpecidas, abre a vista obscurecida

${ }^{44}$ Por se situar no istmo, Corinto era banhada pelo mar Jónio e pelo Egeu, e daí o qualificativo "Corinto dos dois mares". O qualificativo bimaris aparece já nos autores antigos, tais como Horácio: Aut Ephesum bimarisue Corinthi moenia (Od. 1.7.2-3). 
e, para regressar à velha luz do dia, oferece os olhos enfermos aos raios escaldantes. Desta forma, o débil pássaro

535 obtém as dádivas do calor, de cujo estímulo recebe as forças, reparando as perdas de uma idade avançada.

Para não serem únicos os dons que o ardente calor lhe infunde, três vezes mergulha, através da profundidade líquida, nas ondas, para se limpar deposita a velhice nas águas e levanta-se da fonte 540 com uma jovem aparência de beleza ${ }^{45}$. Que acto mais evidente de religião poderá existir? Quando somos tocados pela luz do verdadeiro Sol, perdemos as manchas da idade avançada, com a aproximação da fé; depois, renascidos na água mãe, parecemos toscos pela novidade; de novo surge para o ancião

545 a infância renovada e, para quem fica com dupla natividade, é este o melhor nascimento. Aquele a quem o Espírito concedeu exercitar com mão virtuosa a cítara, bem consciente do exemplo desta ave, disse: "Serás renovado à maneira da águia." ${ }^{46}$ Segundo tal preceito, aos confirmados é dado saberem

550 que agradam pela glória da imagem que os cânticos do justo [confirmam.

Nem está o ofício de Paulo, exercido junto do mesmo companheiro, isento da excelência de um bem escondido. Ele fabricava certamente

${ }^{45}$ Hillier (1993 180-193) dedica um capítulo do seu livro à discussão desta matéria: a relação entre Áquila e a águia (aquila, em latim), tendo por base o inusitado rejuvenescimento da ave por acção da água e da luz solar e o rejuvenescimento através do baptismo, e as fontes de Arátor nestas consideraçóes. Hillier considera que, embora haja outros textos que apontem para este lendário comportamento do pássaro, Arátor se inspira no texto do Physiologus Latinus, uma colecção de fábulas fantásticas sobre animais e plantas, que, no capítulo 8, regista esta história do rejuvenescimento da águia.

${ }^{46}$ Cf. Sl. 103.5: "É ele quem cumula de bens a tua existência, de tal modo que a tua juventude se renova como a da águia”. 
tendas robustas para os móveis abrigos dos acampamentos; e o viajante estrangeiro, peregrinando por toda a parte, monta-as e com estas peles se protege quer do frio quer do sol. Também nós, expulsos da primeira casa pelo pecado, somos [lançados no exílio deste mundo; mas foi restituído finalmente o caminho por onde é possível reiniciar a viagem rumo à pátria. Tenhamos [nós, ó Paulo, abrigos no teu acampamento, para que a tempestade do mundo não nos atinja com as chuvas do pecado, e o incendiário tentador nấo nos acerte com o calor dos crimes! Protegida com tal cobertura, a salvação não enfrenta nenhum golpe de perigo, nem sucumbe prostrada ao poder do fero inimigo. Os chefes enviam sinais místicos nos méritos da sua arte: engodando peixes, Pedro pesca os homens - o hóspede do mar permanece agora nas águas sagradas; enquanto ergue habitaçôes terrenas, Paulo ensina a edificar as celestes, e os aposentos, tantas vezes erguidos pela própria máo, constrói-os agora pela palavra.

\section{[Secçáo X]}

[Passo em que S. Paulo, tendo questionado doze homens em Efeso sobre o Espirito Santo, the responderam que não conheciam esse nome, pois tinham sido baptizados por João; e a estes Paulo ensinou que o baptismo de João foi dado em nome do que havia de chegar, baptizando-os com o baptismo de Cristo; e o Espirito Santo veio sobre eles, concedendo-lhes imediatamente o dom de várias linguas.]

Tendo iluminado as terras e buscando campos mais afastados, Paulo ensina ao chegar a Éfeso e, olhando alguns homens 
que aí estavam, pergunta como inquiridor: "Acaso o Espírito Divino já chegou até estes?” Os próprios lhe dizem que recentemente haviam sido imersos na fonte de João, e que tinham chegado até ali sem conhecer esse nome. Lavou-os no rio sagrado,

575 e imediatamente o Espírito Santo lhes encheu as bocas e lhes concedeu uma chuva de palavras com os poderes habituais. Muitas vezes, partindo deste passo, movem os ímpios as armas e preparam-se para a luta: para lhes poder lançar pela palavra dardos contrários, tu, Espírito Divino, molha agora com maior abundância 580 os lábios meus, para que os ensinamentos que me concedeste sejam dignos de ti! Tu, caminho da palavra, tu, vereda da

[linguagem, és tu que hás-de falar, vem, tu que pelas tuas dádivas sempre fazes com que regressemos e nos recuperas o uso do dom $!^{147}$ João, precursor no mundo, apresentou o seu baptismo

585 em nome do que estava para vir, e ele mesmo preparou o caminho para o Senhor, lembrando a todos que outro baptismo havia de chegar, administrado com autoridade ${ }^{48}$, e que o triplo

[poder costuma iluminar. Mas é mais o facto de Cristo ter escolhido tocar as águas deste ${ }^{49}$ que o torna exemplo para todos correrem até si 590 através da piedosa fonte, para não mais se separar

${ }^{47}$ Esta invocação do poeta (vv. 579-583) não é despropositada. $\mathrm{Na}$ verdade, Arátor pede forças para rebater convenientemente a heresia donatista que, tomando por base esta passagem dos Actos (19.1-6), advogava a possibilidade de repetição do baptismo, dependendo a iteraçáo do sacramento da probidade do ministrante. A essa refutação, o poeta vai dedicar os restantes versos desta secção (584-622).

${ }^{48}$ Cf. Mt. 3.11-12, Mc. 1.7-8, Lc. 3.16-17, e Jo. 1.26-27.

${ }^{49} \mathrm{O}$ baptismo de Jesus por João Baptista aparece relatado em Mt. 3.13-17, e Lc. 3.21-22. 
a raça humana da onda sagrada, que até o Senhor julgou digna do seu corpo impoluto, tendo purificado a corrente, quando Deus foi imerso pela mão do seu servo. Já depois de ter tocado o rio, delegou tal tarefa nos discípulos ${ }^{50}$, que, segundo proclamam [as Escrituras, baptizaram muita gente. Legítimo foi ter cessado o baptismo do seu servo com a chegada do de Deus, sobre o qual o Precursor dissera já antes tais coisas. Na altura em que Jesus tornou [possível ministrar os baptismos já em plenitude ${ }^{51}$, porque haveria João de dar, como antes, o baptismo habitual e que era dele? Esta regra impeliu Paulo [a dizer] que eles deviam renascer na fonte de Cristo. Apontando com o dedo náo aquele que estava para vir mas o que já tinha chegado, João apresentou o Cordeiro Celeste, anunciando que ele tirava os pecados de todo o mundo ${ }^{52}$. Porque queres, ó infiel, fingir que se trata de um duplo baptismo? Não se itera o que é diferente; a repetição mantém a mesma coisa, não outra, e existiria duas vezes aquilo que começou a existir primeiro e a si mesmo regressou. De facto, embora sejam diferentes a fonte primeira e o remate que se lhe seguiu, é evidente que [se trata de um só, dado uma só vez, e nenhum erro sobrecarrega os [baptismos] que, quando comparados entre si, podem comprovar-se as suas diferenças. Mas quando alguém, carregado de negridão, é manchado pelo herético lago do Averno, se deseja obter a luz na fonte da Igreja sagrada, a nossa fé não o obriga

${ }^{50}$ Cf. Mt. 28.19: "Ide, pois, ensinai todas as naçôes, baptizando-as em nome do Pai, do Filho e do Espírito Santo".

${ }^{51}$ Cf. Mc. 1.8: "Eu vos baptizei em água, mas ele baptizar-vos-á no Espírito Santo".

${ }^{52}$ Cf. Jo. 1.29: "Eis o cordeiro de Deus, que tira o pecado do mundo". 
a voltar às águas só porque professa crenças erróneas

615 em nome da Trindade; nem tem por hábito investigar quem são, mas que sacramento podem dar aqueles que as mãos impostas [ensinaram a confessar a verdade, e apenas é repelido o erro, que arrasta para direcçóes opostas o que o Espírito torna uno ${ }^{53}$. Lembra a Escritura que também estes eram duas vezes seis.

620 Oh, sagrada e feliz dimensão do número! Quando, com uma [larga multidão, os alimentos se dignaram nascer da semente dos restos, a glória da lei apostólica foi levada em igual número de cestos ${ }^{54}$.

\section{[Secção XI]}

[Passo em que, concedendo S. Paulo em Éfeso a cura de variadas formas, sete judeus tiveram a pretensão de impor as mãos num possesso, dizendo que o faziam em nome do Cristo que Paulo pregava; e a estes o demónio esconjurado pô-los em fuga, depois de lhes responder; tendo conhecimento disto, o povo acorreu ao baptismo. E alguns até queimaram livros de magia, avaliados em cinquenta mil moedas.]

Já Paulo, vigoroso na palavra, convertera a cidade de Éfeso, e refulgia a sua glória nos sinais celestes.

${ }^{53}$ Embora documente a sua argumentação apenas com passagens bíblicas, julgamos que Arátor tem presentes os escritos anti-donatistas de Sto. Agostinho, nomeadamente as Epistolas 93 e185.

${ }^{54}$ Cf. Mt. 14.17-21, Mc. 6.38-44, Lc. 9.13-17, e Jo. 6.8-13. Tal como na multiplicação dos pães os restos foram recolhidos em doze cestos, assim também os doze apóstolos, fiéis depositários da doutrina cristã, levaram a fé aos povos. Registe-se ainda a simbologia do número doze que, por ser múltiplo de três, acentua, uma vez mais, a crença na fé trinitária. 
E porque os corpos dilacerados vacilavam pelas incontáveis doenças - nem a medicina aplicada pela mão de especialistas reconfortava os míseros doentes -, embora dele afastados, pretendiam para si mesmos as vestes sagradas, de tal modo neles existia uma fé ardente que aquela febre diminuía e outra chama punha fim ao calor. Em suma, os aventais e os lenços de Paulo, oferecidos em público e espalhados sobre os membros, pressionavam os fogos das doenças, e as enfermidades entranhadas no corpo desvaneciam-se por completo: o toque era a força que tudo curava, e lar algum carecia da dádiva que iam buscar à veste medicinal. Sob este mesmo poder, também a minaz turba dos espíritos fugia como pedaços inúteis de fumo pelos ares, para que a bela oficina do Criador, que, moldada a partir da terra, adquiriu a semelhança da imagem celeste e tem por penhor a aparência do seu obreiro ${ }^{55}$, não fosse manchada pelo seu hóspede, e o cheiro do ladrão não infestasse o templo da formosura. Nessa altura, sete homens de raça judaica empreendem novas batalhas. Assim falaram primeiro: "Aquele que Paulo anuncia, Jesus de seu nome, também nós do mesmo modo to [apresentamos; abandona o lugar por ti invadido!" Uma voz lhes replicou: "Sei quem é Cristo e sei quem é Paulo, mas a vós é-me permitido ignorar-vos como estranhos." Conhece, povo hostil, a tua loucura! Até o Demónio confessa que reina aquele que tu negas ter chegado; e és contrariado até por aquele cujo aguilhão te arruína, a ele não lhe foi concedido ser aprazível de boca, que movimenta com pavor; a causa de Deus, que a lei

${ }^{55}$ Formado a partir do barro (daí o nome «Adão»), Deus criou o homem "à sua imagem e semelhança», tal como se afirma no Génesis (1. 26). 
do amor acompanha, proíbe-o de dizer o contrário dos seus intentos. É esta a verdadeira fé. Então, que espectáculo para o povo e que coroa triunfal, na vitória do Senhor, daí aconteceu,

655 quando, rangendo os dentes num murmúrio enraivecido, a ira tão maligna do demónio rasgou os mantos aos seus e lhes dilacerou as faces, e eles, vencidos, fugiram do perigo, virando as costas nuas num precipitado terror! Por que razão, cruel Judeia, não temerás agora a destruição,

660 se assim pereces às mãos do aliado inimigo, se para ti o instigador e o castigador do crime é o mesmo, e se, para não ser expulso [contigo por juiz, ele é o réu, enquanto tu és a culpada? De imediato, voando [por toda a parte, se espalhou pela cidade a notícia de que até a voz do demónio [anunciava que o supremo poder é o de Deus. Regozijam-se por ir ter com ele, 665 entrar nas águas sagradas e lavar as velhas máculas na nova fonte e por resplandecer através das santas correntes, pelas quais uma única idade de inocência é a todos dada ao [mesmo tempo.

Outros, porém, ateiam fogo aos livros de magia, para serem merecedores das águas e, pelo fogo, escaparem ao fogo.

670 A imensa e elevada chama, cujo esplendor voa por sobre os ares, e as numerosas fagulhas atingiram o céu. Estimaram ainda o valor dos livros em cinquenta mil moedas, pois foi assim que os culpados mereceram eliminar o seu pecado. A razão desta figura é a seguinte:

675 na Lei, este número sagrado apagou os pecados; por exemplo, outrora David, por todo aquele Salmo ${ }^{56}$, dissipa as suas faltas

${ }^{56} \mathrm{O}$ número cinquenta (das 50.000 moedas em que os judeus 
e, arrependido, afugenta-as: com efeito, ao chegar o quinquagésimo ano do Jubileu, a posse do terreno próprio é devolvida ao antigo dono, a liberdade perdida volta aos que foram coagidos a servir, o credor abre máo das dívidas perniciosas, e o velho exilado contempla o limiar da pátria ${ }^{57}$. Tinha também a largura de cinquenta côvados a arca que, mergulhada nas águas e a salvo no mar, leva a salvação no número da misericórdia ${ }^{58}$ e vai crescendo, resguardada pelo auxílio da largura do perdáo, pois Cristo fundou por toda a parte, ampla pela graça edificante, a Igreja, que, tendo assim começado nas ondas, se estende vastíssima [pelos campos.

\section{[Secção XII]}

[Passo em que um ourives de prata, Demétrio, fabricante em Éfeso de sacrários de prata para Diana, incitou à revolta contra S. Paulo. Após o discurso daquele, a multidão irada precipitou-se para o teatro, onde o tumulto destes loucos se esvaneceu em nada.]

Em Éfeso, o desventurado Demétrio colocava graças à sua arte sacrários de prata em lugares sacrílegos, acostumado

avaliaram os livros queimados) simboliza a penitência e a remissáo dos pecados. Para atestar a simbologia, Arátor remete para o Salmo 50, que é um sentido apelo à misericórdia de Deus.

${ }^{57}$ É o segundo exemplo de Arátor para atestar simbologia do número cinquenta. Também a cada cinquenta anos se celebra, entre os Judeus, o Jubileu, que se traduz no perdáo de dívidas, no regresso dos expatriados, na retoma das terras perdidas. Cf. $L v$. 25.10-22.

${ }^{58}$ Terceiro exemplo da simbologia do cinquenta: também a arca de Noé, que haveria de salvar os que nela embarcaram, pautava as suas dimensóes por este número. Vd. Gn. 6.15. 
690 a fazer ofertas de elevado valor à sua Diana.

Vendo desaparecer todos os memoriais da antiga loucura, rugiu e atiçou rancores vãos com estas palavras:

"Não vos envergonha, companheiros, que a nossa Diana, a quem a estima do mundo venerou, tenha caído? Que salvação

695 podem esperar doravante os mortais, se os deuses não podem privar-se do fim ao longo dos tempos? Que estátuas se poderão agora ofertar aos santuários, que incensos, ao fogo? Paulo, um estrangeiro, aterroriza-os e, a tudo quanto fazemos em nome dos deuses, chama mudos metais; o seu culto desapareceu

700 da terra, e os Penates expulsos puseram-se em fuga ${ }^{59}$. Ai de mim, vejo já os santuários, há tanto tempo edificados, caírem em inesperadas ruínas, e até o edifício do famoso templo ser votado às cinzas e à destruição! Que cidadela nos resta, e que poder temos nós a quem foi interdita a permissáo

705 de trabalhar e nos imputam como crime ter criado Diana? Vamos! Chegou a hora. O esforço derradeiro tem tudo do seu lado, se estiver em desespero; para os vencidos, nada temer é o [único caminho da vitória; está reservado um destino certo de triunfo para quem move as mãos a favor das coisas do alto. Insurgi-vos [com dardos,

59 Como é sabido, os Penates eram os deuses domésticos. Arátor segue o passo dos Actos dos apóstolos (19.23-40) que se limita fundamentalmente a acentuar o prejuízo de Demétrio e dos demais artífices que, com a pregação de Paulo a pôr em causa a divindade de Ártemis, tinham o seu negócio em perigo. Todavia, num subtil acrescento ao texto lucano, o poeta aproveita para se insurgir contra os deuses romanos e contra a idolatria em geral. Tal como acontece nas invectivas contra o Judaísmo, também neste caso há um claro objectivo de defesa da ortodoxia cristá, mesmo que tal implique um claro afastamento relativamente ao texto bíblico. 
e que as armas reclamem de novo esta deusa que as oraçóes veneram!"

Movido por estas palavras, indigna-se o povo e, gritando em uníssono, chama grande a Diana e, numa corrida alada, em grande tumulto se dirige para o obsceno teatro.

Nenhum outro fórum seria mais conveniente para os devassos defenderem a causa e o mérito de Diana: um lugar imundo acolhe o acto da ignóbil reunião. Mas o demente entusiasmo desapareceu como o fumo que se esvai pelos ventos invisíveis ao olhar e, ao dispersar-se, não deixa rasto algum. Oh, deplorável bando! A quem te empenhas tu em engrandecer? Por que razão a julgas eterna? És testemunha de que a fugitiva se escapa dos seus santuários. Por que razão temes e sofres por ela, moribunda, e tentas associar ao céu quem negas ter permanecido na terra? A disposição da figura deveremos agora sondá-la e vê-la nos seus mistérios revelados: diz-se que o louco Demétrio construiu moradas para a deusa apenas de prata, embora a natureza tenha produzido vários outros metais no seu amplo seio, com os quais as [poderia modelar, tal como os bronzes parecem animar-se com os rostos fundidos, e as mãos talentosas lançam rochas para a vida. Ora, se folhearmos os livros da palavra sagrada por ordem, acharemos o caminho, pois a Escritura compara o ouro aos sentimentos puros, e a prata às palavras resplandecentes ${ }^{60}$. $\mathrm{E}$, embora o Salmo possua tal cantar ${ }^{61}$, tu, porém, ínclito Moisés, mais profundamente o recordas, ao dirigires ao povo tais palavras: “Trazei ouro e prata para o adorno dos templos!”62

O que fica mais no interior da mente não é a rija substância
${ }^{60}$ Cf. Job 28.12-17, Sl. 12.7, e Sab. 7.9.
${ }^{61}$ Cf. Sl. 105.37: "Fê-los sair com ouro e prata".
${ }^{62} \mathrm{Vd}$. Ex. 25.3: "Recebereis deles as seguintes ofertas: ouro, prata [...]". 
de metal que o coração esconde, mas estimula mais vivamente aquilo que Cristo ama. A mente que tiver a preciosa fé oferece o ouro, e de igual modo ministra a prata

740 aquele em cuja voz ressoam os bons tambores do coração, para venerarem o Senhor os dois juntos: o sentimento vindo do coraçáo, o som vindo da palavra. Assim, os preceitos da Lei exigem que se prepare este ouro e esta prata para os piedosos templos. As proféticas palavras ensinam-nos o que o Apóstolo também revela,

745 que nós somos templos, se forem afastados todos os pecados. A salvação estará no coração do crente, a confissão, na sua voz ${ }^{63}$. Para o sacrílego havia apenas uma coisa: Demétrio, cuja eloquência fez agitar aqueles espíritos, construiu templos em prata, para que a regra pudesse fazer prova de que as divindades vãs

750 são veneradas sem terem por juiz o entendimento, e de que tal culto não provém da virtude do coraçáo; a ele apenas é dedicada esta parte que, privada da razão, com a boca espalha nuas palavras.

\section{[Secçáo XIII]}

[Passo em que S. Paulo, prolongando em Tróia até alta noite a sua pregação numa sala, mandou acender lâmpadas; e aí o jovem Eutico, que dormia numa janela, caiu do terceiro andar e foi encontrado morto lá em baixo; Paulo abraçou-o, dizendo que a vida ainda estava dentro dele; e o rapaz, tendo ressuscitado, foi reconduzido ao primeiro andar, onde Paulo pregava.]

E tu, Tróia, agarrando os sinais, repóe teus títulos no nosso poema e junta aos teus louvores os triunfos

755 que, por serem verdadeiros, te conferem muito mais brilho

${ }^{63}$ Cf. Rom. 10.10: "Porque com o coração se crê para alcançar justiça, e com a boca se confessa para alcançar a salvação". 
do que os eventos ecoados por tuas guerras nas pomposas tragédias. ${ }^{64}$ A língua que cultiva Deus, espalhando as sementes repletas de salvação, alongou as horas pela noite demorada, para trazer a mais almas o dia; palpitaram as lâmpadas cintilantes para brilharem os fiéis com o fogo da palavra. Êtico, sozinho, longe dos vigilantes atentos, confiou à janela o corpo mergulhado no sono profundo. Oh, descanso mal ganho! Oh, coraçôes sempre rendidos ao sono e despidos do bem! A que desastres tamanhos está exposto quem só a noite guarda e nunca ergue a cabeça enferma para mais altos bens! Náo pode ser vigilante no perigo quem se permite adormecer para Deus. Porque procuras, jovem, o caos vazio da janela e porque descansas nesse lugar por onde sofrerás a queda? É coisa inimiga para a saúde procurar um alto declive e querer desfrutar de secretos sonos num leito inclinado. Podias repousar numa cama bem melhor, na palavra de Deus, e, seguindo o conselho de Paulo, escolher outra entrada, a daquele cujo nome é porta, acessível pelo limiar da justiça e através da qual as ovelhas erguidas da fonte caminham em direcção à vida ${ }^{65}$. Procurai-a todos vós, se vos preocupais em escapar às fauces violentas e às dentadas sanguinárias do lobo, por cuja boca será destroçado

${ }^{64}$ Famosa por servir de cenário a obras-primas da literatura clássica, quer épicas quer trágicas, Tróia adquire agora, na perspectiva de Arátor, um brilho maior, na medida em que o protagonista é um herói que se superioriza face aos antigos: os seus feitos são reais e não lendários, e a sua conduta é excepcional e irrepreensível do início ao fim (o que náo acontece, por exemplo, com o Aquiles homérico).

${ }^{65}$ Cf. Jo. 10.7-9: “Tornou, pois, Jesus a dizer-lhes: Em verdade vos digo que eu sou a porta das ovelhas. [...] Eu sou a porta: Se alguém entrar por mim, salvar-se-á; entrará e sairá e achará pastagens". 
quem fugir do pastor, que chama os cordeiros dispersos pelos nomes e náo consente que o rebanho, redimido

780 pela sua própria morte, seja de novo capturado pelo inimigo, por armadilhas e pela ferida do seu amargo dente. A sala ecoou num tumulto funesto; a lastimosa multidão, num gemido reiterado, correu para ver o lugar que, entristecido pela morte prematura, se transformaria em fonte de alegria. Paulo, cingindo-o

785 contra o peito, diz: "Está vivo!" A vida acompanhou estas palavras, e a morte, repelida, pôs-se em fuga. Que altos feitos consegue, ó Cristo, o teu poder a trabalhar nos teus servos! Tu, regressado dos Céus e igual ao Pai em eterna majestade, reges as leis celestes. Mas porque a tua carne, nascida

790 do corpo de uma mãe virgem, pilhou o reino do Averno, e de volta trouxeste o corpo vivo do teu próprio sepulcro e, provando que quiseste morrer, ressuscitas nessa parte de que tinhas nascido, soltando táo férreos grilhôes, por isso é que, graças a ti, regressa às outras uma segunda luz,

795 também concedida pelo teu exemplo, tu que obrigas os Tártaros há pouco subjugados a renderem-se também aos teus servos eleitos. Entretanto, ergue-se da morte o corpo feliz e, são e salvo, através de três andares é conduzido por um caminho melhor até Paulo, para cujos olhos

800 o rapaz inocente começa já a ser digno da honra da vida, pois alterou o caminho da morte. A glória de tal feito ensina-nos a explicar as causas, de acordo com a antiga figura: na sua descrição, a arca de Noé está sustentada por três andares ${ }^{66}$ que representam as liçôes da Igreja; ocupou a posição do primeiro

805 a parte humana, o gado ficou com o segundo andar,

${ }^{66}$ Cf. Gn. 6.16: “Colocarás a porta da arca a um lado, construirás nela um andar inferior, um segundo e um terceiro andar". 
a terceira porção foi reservada às feras. A arca quadrada os transportou, todos juntos, pelas ondas, tal como no baptismo [da fonte há agora uma única salvação para todos, mas não pode haver um único lugar para as acçóes. De facto, diz-se que ninhos foram nela construídos por Noé, que em hebraico quer dizer 'o justo' e 'o descanso', pois nele já estava Cristo, que divide com equidade recompensas certas pelos seus. Qualquer amante da virtude,

[que procura altos valores, junta-se a Noé; imediatamente abaixo, pelo seu carácter, se situam os menos dignos; a porção mais baixa, reservada aos animais selvagens, representa o seio do Tártaro. Portanto, Êutico, caindo assim do primeiro lugar, andou perdido nas margens do Inferno e, desprovido da humana razão, começou a tomar lugar junto das feras. Depois de Paulo o cingir contra o peito e de sabiamente o aspergir com a sua palavra, erguendo com os lábios a alma aniquilada pela lei da carne, ele regressou da morte para o Senhor, algo que a Epistola proclama: “Tu que dormes, levanta-te depressa!” E de novo insiste: "E tu, vigilante, ergue-te da morte!" $67 \mathrm{O}$ rapaz foi então digno de ascender à terceira elevação, pois na fé da Trindade descobriu qual é a substância da vida eterna.

${ }^{67}$ Cf. Ef. 5. 14: "Desperta tu, que dormes. Levanta-te do meio dos mortos, e Cristo brilhará para ti”. 


\section{[Secçáo XIV]}

[Passo em que S. Paulose despediu na praia dos anciäos convocados da Asia, falando-lhes e dando-lhes múltiplas advertências, mostrando que tinha pregado durante três ininterruptos anos, dizendo que iria a Jerusalém e sofreria muitas provaçöes e que näo mais o veriam, aconselhando-os a darem esmola; em seguida, ajoelhando-se, rezou e afastou-se das multidóes chorosas, a quem beijou, avançando para o navio.]

E percorridos já os destacamentos do mundo, Paulo estava prestes a chegar a Jerusalém, para onde o Espírito tantas vezes o aconselha a avançar. Desejando, na famosa praia, dizer um perpétuo adeus, convoca todos os santos de todas as partes,

830 dizendo-lhes estas palavras do fundo do seu amistoso coração: "Ó amadas tropas, que militais com as armas de Cristo!

Ó gente nascida do Deus altíssimo! Lembrai-vos dos ensinamentos do meu amor e do meu zelo; enfrentei com coragem as multidóes dos gentios e as loucuras infindáveis dos Judeus,

835 para ofertar os preceitos da vida, e a fé divulgada entre o povo náo ser por ninguém ignorada. Do vosso sangue sempre eu estarei limpo, e não pagarei os talentos escondidos ${ }^{68}$ como devedor de boca avarenta e, na sementeira da palavra, o campo árido não me acusará de estéril; convém que dele

840 tireis o sagrado lucro, pois há-de chegar o Criador, que examinará os ganhos e aos seus servos exigirá o aumento da sua medida. Nos meus sentidos havia a paixáo de levar as sementes que, confiadas a toda a terra, espalhámos pelos sulcos, mas o solo mau há-de chorar os escassos frutos.

845 Vou ver a cidade da cruz, venerável para as naçóes,

${ }^{68} \mathrm{Cf}$. as seguintes parábolas bíblicas: parábola dos talentos $(\mathrm{Mt}$. 25.14-30) e parábola das moedas de ouro ( $L c .19 .11-26)$. 
aonde as ordens me chamam; aí me será dado enfrentar a luta de um combate diferente, pois tudo suportará quem desejar concluir a corrida; dulcíssimo é o quinhão dos castigos que a vontade almeja, e poder real é sofrer pelo rei perpétuo. Velai, ministros, pela Igreja de Cristo, que com o seu sangue edificou como recompensa para nós neste mundo que é seu. Trabalhem os servidores para conservar o que o Senhor ofereceu com a morte. Nunca mais vereis a minha face e o meu rosto. Vigiai, rogo-vos, mais atentamente os rebanhos a vós confiados, porque os lobos de ávido dente hão-de convergir para o redil! A culpa é do guarda, se o saqueador fugir com o roubo; pela incúria do mau pastor se perde o que o ladrão arrebata. Mas se o inimigo estiver lá dentro mais devastador será, e a guerra, que já em tempos de paz [causa aflições traz um mal ainda pior. Não cedais às dificuldades!

O descanso é danoso para a virtude, e o valor negligente a ninguém coroa no estádio; para o corajoso, o motivo do labor será a sua glória, e raramente é premiado o soldado que só conheceu a paz: a vitória retira a sua semente do inimigo, daí é que ela nasce. Tem o poder de fertilizar os vossos rebentos o Senhor ${ }^{69}$, que pelos seus dons nos faz chegar aos seus dons, e ele mesmo fornece todo o auxílio. Eu não arrecadei esplêndidas riquezas num luxo enganador como pagamento recíproco, nem arrebatei dádivas, ao procurar-vos a vós em lugar dos vossos bens; bem sabeis como estas mãos 870 me alimentaram a mim e aos meus companheiros. Habituai-vos [a apresentar

${ }^{69}$ Cf. 1 Cor. 3. 7: "Assim nem o que planta nem o que rega é alguma coisa, mas só Deus, que dá o crescimento". 
as riquezas nas estradas da luz e a colocar os tesouros das obras nas moradas do Céu! De nada há-de adiantar ter buscado ouro em recônditos lugares, se o avarento enclausurar

875 o que antes a terra escondia; o ouro que o mesquinho não mostra é como se jazesse na terra e fosse devolvido à cega gruta pela sombria mão do pecador. Abri os coraçóes, imploro-vos, aos conselhos divinos, e que ninguém se recuse preparar tectos para o rebanho carenciado, pois nesse hóspede recebe a Cristo ${ }^{70 !}$

880 Depois de assim falar, beijou-os e, enquanto orava, flectiu sobre o chão os joelhos e todos, constrangidos pela dor, derramaram piedosas lágrimas e, de longe, mereceram seguir o navio pelas ondas, numa contemplação que o acompanhava. $\mathrm{E}$, enquanto lançam o olhar por entre as nuvens interpostas, 885 um caminho para o mar se oferece aos olhos, e o barco, arrebatado pelas brisas, é ainda vislumbrado e acaricia as mentes com sua imagem, e a capacidade da visão cresce graças à afeição da alma. Mas, porque ele disse "Durante três anos, dia e noite, vos dei estes ensinamentos para vossa salvação", uma figura se revela pela [seguinte razão:

890 quem canta os três dogmas da Igreja com maior frequência apresenta um volume que faz ecoar o sentido histórico, o moral e o tipológico ${ }^{71}$.

${ }^{70}$ Cf. $M t$. 25.40: "Em verdade vos digo: sempre que fizestes isto a um destes meus irmãos mais pequeninos, a mim mesmo o fizestes".

${ }^{71}$ Este verso de Arátor é um dos mais citados e comentados pelos seus estudiosos, uma vez que ele contém a perspectiva para o tratamento que o poeta faz do texto glosado, os Actos dos apóstolos. Uma perspectiva ou projecto de intençóes que, aliás, está já patente na Carta a Vigílio, quando Arátor afirma: Alternis reserabo modis, quod littera pandit / et res si qua mihi mystica corde datur (vv. 21-22). Ao sentido histórico (quod littera pandit) e moral (res mystica), já enunciados na carta, acrescenta agora Arátor o sentido tipológico, sendo, como se sabe, a tipologia bíblica um recurso muitíssimo frequente do poeta na interpretação de passagens veterotestamentárias. 
$\mathrm{Na}$ verdade, as seis vasilhas que coraram com o novo líquido saído da velha Lei contêm assim três medidas ${ }^{72}$.

$\mathrm{O}$ antigo ritual do sacrifício perfeito prescreve que se ofereçam do cesto três espécies de pãa ${ }^{73}$; a estes se junta o que Cristo disse aos discípulos, que se deviam dar três pães a quem os pedisse mesmo sendo já noite ${ }^{74}$. O mundo é, sem dúvida, essa noite, de modo que, se alguém aqui desejar o alimento da palavra, tu, que recebeste o pedido, lhe sirvas um banquete e ensines [a quem o desejar que o Pai e o Filho juntamente com o Espírito Santo são um só Deus e que uma única substância triplica o número. As ordens divinas não proclamam isto uma só vez. Diz ele: "Se alguém te força, exigindo-te que vás à sua frente durante [uma milha, acompanha-o por mais duas!"75 Tais ordens parecem certamente dizer o seguinte: Se alguém em erro e desconhecedor do caminho te consultar, saibas tu dizer-lhe o que é Deus, apresenta-lhe o Pai, acrescenta com prazer que existe o Filho e o Espírito Santo, três em número, um único, porém! Por isso, a oca Judeia, que é chamada árvore estéril, estando à espera, não deu fruto naqueles três anos ${ }^{76}$, porque, recusando discutir os seus livros no triplo sentido, não soube dar a Cristo as dádivas nos números da fé.

${ }^{72} \mathrm{Vd}$. Jo. 2.6.

${ }^{73}$ Vd. Ex. 29.2 e 23.

${ }^{74} \mathrm{Vd}$. Lc. $11.5-8$.

${ }^{75} \mathrm{Vd}$. Mt. 5.41. Cf. também Lc. 11.5-6.

${ }^{76} \mathrm{O}$ anti-semitismo de Arátor está patente na interpretação que faz da parábola da figueira estéril (Mt. 21.19, e Lc. 13.6-7). Noutros passos bíblicos, também se afirma que toda a árvore infrutífera deve ser cortada e lançada ao fogo: cf. Mt. 3.10, 7.19, e Lc. 3.9. 


\section{[Secção XV]}

[Passo em que S. Paulo foi preso no templo de Jerusalém pelos judeus. O tribuno arrancou-o das mãos daqueles que o queriam matar e lançou sobre ele duas correntes. Ele expôs, em hebraico, a razão por que se convertera ao Senhor; e, quando disse que este lhe ordenara partir dali e ir pregar aos gentios, gritaram que ele devia ser banido e perder a vida; e atiraram com as suas vestes e com poeira para o ar; fala-se ainda de uma questão a propósito de uma contradição de palavras, agora resolvida.]

Paulo tinha já começado a aproximar-se do famoso templo de Salomão e a cumprir as solenidades da velha lei.

915 Eis quando um grupo de judeus se apoderou dele e, com [furioso tumulto, gritam que ele estava condenado à morte, mas, entre as armas, acorre o tribuno e ordena que fosse preso com duas correntes. Todavia, os duros tormentos que se abatem sobre os braços atados não lhe prendem o espírito, porque a Epistola de Paulo,

920 cheia de luz, proclama que se podem atar os servidores, mas não se pode atar a fé, e não é possível pelas torturas reprimir a palavra ${ }^{77}$ E, nos próprios degraus, parou, falando ao povo num discurso em língua hebraica: "Ó homens, irmãos e pais! Sabeis que vim a estas

925 margens sem instrução; consagrei-me, com paixão, a cada ensinamento da Lei; tomo-vos agora por testemunhas: ao levar as vossas cartas, desejava ardentemente castigar com a morte, em Damasco, as gentes veneradoras de Cristo e banir essa fé

${ }^{77}$ Cf. 2 Tim. 2. 8-9: "Lembra-te de Jesus Cristo [...], pelo qual eu sofro estas cadeias, como se fosse um malfeitor. Mas a palavra de Deus não se deixa acorrentar". 
dos confins do mundo. Mas não podem os mortais pelejar com o seu Criador. Dos céus baixou uma luz que me havia de fechar os olhos e, desse fogo resplandecente, se escondeu a luz brilhante do dia, e sobre meus olhos se abateram escuras trevas, cujo brilho, a seu tempo, cresceu para mim, chegando juntamente com a noite. O desenlace, depois dos

[acontecimentos, costuma elucidar as causas; bem nos apercebemos das sombras, prestes a desfrutar do novo Sol. Mas também um brado, vindo [da boca de Deus, esteve hesitante em meus ouvidos; repetindo o nome

['Saulo',

Cristo aterradoramente me sacudiu, para não mais ousar combatê-lo como alferes. Com que direito poderei negar aquele por cujo golpe me vergo, por cuja dádiva eu, prostrado, me levanto por um caminho melhor, saio por vias escarpadas e sigo os dons felizes da minha queda sublime! Concidadãos, já basta de pegarmos em cruéis armas! Nada de duvidoso ensina aquele ditoso grupo que se serve do seu inimigo como testemunha. Porque vos comprazeis ainda

[na culpa?

Brilhai a partir das minhas trevas, pois a fé deu-me em abundância a visão a partir das águas da fonte, e a imagem da morte começou a viver nessas águas!" Ah! Nunca a terra rochosa será fértil com suas sementes, e fazem inútil trabalho os que deixam o solo estéril! "Depois Jesus, numa visão, disse-me finalmente isto: 'Saulo, prepara-te para ir para longe, para muito longe, depois de abandonares esta cidade. Ela não há-de acreditar através de ti no nosso nome. As palavras da salvaçáo, canta-as antes aos gentios!"” Imediatamente as ruidosas falanges the cortaram a palavra. 
955 Atiram com as vestes e, sacudindo para longe o pó, vociferam com leviandade arrogante, e o povo enraivecido grita em imensa algazarra, colocando Paulo em apuros. Oh, Judeia malvada! Desejando destruir o autor da vida, falaste nos mesmos termos. Oh, clamorosa, tiveste a opção

960 de poupar quem tu quisesses, mas exiges, maleficente, com palavras sangrentas, o triste sacrilégio e celebras as alegrias da Páscoa escolhendo um ladrão, duplicando assim a tua loucura, cruel para com o santo, complacente para com o culpado ${ }^{78}$.

[Em cada luta, despojas-te a ti mesma e apresentas-te nua, quando, mais dura

965 do que elas próprias, atiras pedras contra Estêvão; tiras as vestes e careces agora de roupa, pois o castigo do primeiro pai é similar ao teu ${ }^{79}$, e carregas no corpo o peso do antigo transgressor, hostil para com a glória da fonte, para não te renovares nas águas. Adão, no nascimento do seu pecado,

970 reconheceu a nudez e, a partir daí, as liçóes da sua culpa foram evidentes para o miserável. A repetida origem da morte cresce em ti, em quem a ira repleta de maldade semeia o hábito que o pecado alimenta por duas vezes ${ }^{80}$. Vendo, [entấo, o tribuno que, com tais palavras, recrudescia a violência, lançou mais [atrozes correntes

975 sobre Paulo e enviou-o para o iníquo acampamento a fim de ser torturado. Cantaremos como se deve superar uma famosa divergência de passos:

${ }^{78} \mathrm{O}$ pedido para que Pilatos procedesse à libertação de Barrabás e à condenaçáo de Jesus aparece relatado em Mateus 27.16-23.

79 Também Adão e Eva, depois de pecarem, reconheceram a sua nudez. Cf. Gn. 3.7: "Então abriram-se os olhos aos dois e, reconhecendo que estavam nus, prenderam folhas de figueira umas às outras".

${ }^{80}$ "Duas vezes», isto é, primeiramente na lapidação de Estêvão, e agora no castigo a que os judeus pretendiam submeter Paulo. 
num lugar, Paulo, falando dos seus feitos, diz que os companheiros [viram imediatamente a luz, mas não escutaram com seus ouvidos aquela voz; mas aqui pode ler-se que, no momento em que tombou cego, também os seus acompanhantes ouviram a voz ${ }^{81}$.

Deste modo, não quadra a obra do narrador. Mas urge sem dúvida que ambos os passos convirjam, pois ora se diz que ouviram, que receberam o som, ora que indubitavelmente não ouviram.

Esta será uma forma simples de explicação. Nega-se, e com razão, que uma voz, porque indistinta, tenha falado, pois não se acredita que possa ser dado pela palavra algo que o ouvinte não guarda no coração; quando estimulado apenas pelo ouvido duvidoso, trata-se somente de um estrondo ambíguo que corta os ares; assim, tanto se pode ler que ouviram como que não ouviram ${ }^{82}$. Num passo temos o som, no outro, a certeza da voz, e um só facto comporta num e noutro caso uma dupla imagem.

${ }^{81}$ Arátor procura resolver uma contradição do relato lucano a propósito da conversão de Paulo. Efectivamente, como se pode verificar no texto da Vulgata, os dois passos são contraditórios: Viri autem illi, qui comitabantur cum eo, stabant stupefacti, audientes quidem uocem, neminem autem uidentes (Act. 9.7); Et qui mecum erant lumen quidem uiderunt, uocem autem non audierunt eius qui loquebatur mecum (Act. 22.9). Sublinhado nosso.

${ }_{82}$ Trata-se de uma soluçáo engenhosa para um problema aparentemente insolúvel: segundo Arátor, no primeiro passo dos Actos, audientes nocem tem apenas o sentido de "escutar o som"; assim, na segunda passagem pôde o narrador dizer uocem non audierunt, pois os companheiros de Paulo escutaram mas não comprenderem as palavras de Deus. 


\section{[Secçáo XVI]}

[Passo em que S. Paulo foi torturado no acampamento e martirizado com açoites. Contra ele quarenta judeus juraram solenemente que não haviam de comer ou beber antes de matarem Paulo, quando este fosse enviado ao tribuno Lisias. Depois de um familiar de Paulo ter denunciado tal pretensão, foi de noite enviado pelo tribuno a Cesareia junto do governador Félix, onde defendeu a sua causa contra os judeus e o seu advogado e, depois, perante o sucessor, Festo, junto do qual apelou para César; com efeito, Félix esforçou-se por manter <Paulo $>$ detido para o seu sucessor.]

A situação convida a expor em verso as multidôes ávidas de supliciar o corpo de Paulo e a extrema violência dos castigos, mas a língua fica apreensiva. Fujamos deste

995 passo, minha dor, e, receando tal impiedade, suspendamos táo triste discurso, evitando talvez que o leitor encha de lágrimas seu rosto e com gotas copiosas humedeça esta página. Mas não podiam estes castigos saciar as mentes sanguinárias; arde a paixão do crime, e desejam revolver as sacrílegas

1000 mãos no sangue de Paulo. Que cruéis desejos de maldade! Quarenta filhos de uma geração insana impuseram a si mesmos náo tomar qualquer bebida ou comida antes de lhes ser entregue, já consumado o assassínio, e comer daí maiores iguarias. Oh, pálida imagem do coração!

1005 Taças cheias de sangue, ó Judeia, são para ti melhores do que as de bebida e, sem quereres tocar em mesa alguma, andas esfaimada para o crime e procuras ter a fome aplacada no cadáver do justo. Moisés, pelo seu exemplo, tais jejuns não prescreveu, consumados, como te recordas, em tantos dias 
quantos os dardos que arremessas; e vês que, por igual número de anos,

se iluminaram recônditos caminhos, quando da nuvem abundante fluiu alimento a partir do orvalho e, alternadamente, a árida terra fez verter as águas da rocha. Nesse período, mereceram nossos pais usufruir da divina bondade e com os dons do alto nutrir suas almas ${ }^{83}$, nesse mesmo número, vens tu, cruel, cobrir-te de cólera e juntas os repugnantes juramentos da multidão, para que uma só morte faça numerosos culpados. Disto é informado Lísias, por indicação de um familiar de Paulo, e do lugar onde preparavam a armadilha. Célere ordena, portanto, que as suas instruçóes se mantenham em segredo e, durante

[a noite, cauteloso, adianta-se ao trabalho secreto e instrui os manípulos ${ }^{84}$ escolhidos para acompanharem Paulo, respeitando a sua dignidade. Honrado delator, pelos teus méritos, a glória não te será estranha, e procedes bem ao denunciar, o que raramente conduz à recompensa; e nem a constância que receias manter 1025 em relação ao crime te será nociva. Virtude no crime será crime e, quando os injustos se associam para o mal, é pecado manter aí fidelidade, que a verdadeira honra depois ornamenta

${ }^{83}$ Sendo quarenta os judeus que conspiravam contra Paulo, o poeta sublinha que tal número só aumenta o sacrilégio do acto, como se pode comprovar por dois exemplos do Antigo Testamento: foi esse o número de dias que Moisés jejuou enquanto esperava que Deus escrevesse as tábuas com os dez mandamentos (Ex. 34.28); durante quarenta anos Israel vagueou pelo deserto alimentado e saciado pelas dádivas de Deus (Ex. 16.35, e $N m$. 20.11).

${ }^{84}$ A palavra é etimologicamente muito sugestiva. Manipulus é um molho de espigas ou ervas que, segundo a lenda, os primeiros exércitos romanos prendiam às lanças como insígnias. Daí Manipulus ter também o sentido de "corpo de soldados que combatiam sob a mesma bandeira", como testemunha, por exemplo, Ovídio: Pertica suspensos portabat longa maniplos, / unde 'maniplaris' nomina miles habet (Fast. 3. 117-118). 
no louvor, quando a causa é piedosa. Rodeado de homens armados,

1030 Paulo dirigiu-se de imediato a Cesareia, para onde a multidáo convergiu, apoiada no seu advogado que, tendo conseguido a atençáo do governador, lançou inúteis palavras ${ }^{85}$. Finalmente, Paulo replicou nestes termos: "Excelente governador, todos sabemos que há muito tempo segues os ensinamentos da justiça e que é ela a discreta companheira

1035 nas tuas assembleias; tal reconhecimento convence-me a ter confiança e a não falar com hesitação perante tal juiz. Não violámos o sagrado costume da Lei e do templo, nem agitámos vendavais entre o povo com palavras levianas. Chegado das cidades da Ásia, começámos a cumprir

1040 os votos que tiveram sempre uma intenção pura. Quem, pergunto eu, será livre, se tal faz de um homem culpado? Afirmo sem temer - pois a fé náo pode recear os perigos - que o que ousam chamar seita é o caminho da luz, e que não discordam das novas

1045 as antigas leis dos nossos pais; agora, a todos é permitido acreditar que os corpos já podem ressuscitar dos túmulos, depois de Cristo, que tudo criou, ter daí trazido o seu." Perdendo o sentido do seu nome, ficou atordoado Félix ${ }^{86}$, a quem tornam culpado os grilhôes alheios, por cujo impedimento 1050 Paulo é mantido em prisão até ao ano do governador Festo.

${ }^{85}$ Trata-se de Tértulo, cujo discurso aparece em Actos 24.2-8. Como acontece em várias ocasiôes, Arátor resume o texto bíblico ou ignora mesmo alguns passos de maneira a conceder todo o protagonismo ao seu herói, Paulo de Tarso. Neste sentido, o nome do advogado dos judeus, assim como o do Sumo Sacerdote Ananias (Act. 24.1) são simplesmente omitidos.

${ }^{86}$ A expressão amisso nomine, "tendo perdido o nome", reportase à categorizaçấo morfológica em latim do vocábulo Felix, nome próprio ou adjectivo. Ou seja, perante o discurso contundente de Paulo, Félix perdeu o sentido da felicidade. 
Preterimos aqui muitos factos para não demorarem nossas alegrias, - Vem agora, Paulo, para o Lácio! -, mas leiam-se ainda as intrigas que foram agitadas no amontoado fórum e as enormes artimanhas dos judeus ${ }^{87}$. Com efeito, Paulo dissera o seguinte: "Desafio-vos para o trono de César; como romano, apelo ao auxílio de César." Respondeu-lhe Festo: "Hás-de partir, como desejas, verás muito em breve o tribunal de Augusto." Paulo, escapando aos perigos, mas não pelo aguilháo do medo, evitou o peso do julgamento; estava o pensamento sempre ansioso por morrer em prol de uma vida melhor, mas a origem dos dons já um dia dissera ao seu arauto e testemunha que ele havia de chegar a Roma. Da sua taça, a clemência de Jesus dá a beber a poção da fé aos sequiosos de todas as terras, e ordena que todos sejam irrigados com o discurso transbordante, e o resplendor do nome ocidental mereceu crescer a partir da luz da palavra.

${ }^{87}$ Tendo consciência de que se trata da mais extensa omissão de factos bíblicos, na descrição do périplo do seu herói, Arátor tem necessidade de alertar o leitor para esta circunstância e justifica o seu procedimento: urge fazer chegar Paulo o mais depressa possível a Roma. Na verdade, o poeta omite todos os eventos em torno da relação entre Paulo e o rei Agripa, relatados na segunda metade do capítulo 25 dos Actos (13-27) e em todo o capítulo seguinte. 


\section{[Secção XVII]}

[Passo em que S. Paulo, navegando para Itália sob escolta militar, enfrentou uma tempestade durante catorze dias, encalhou nas sirtes e a equipagem do navio foi despedaçada, de maneira que não viam o sol nem as estrelas, nem se podiam alimentar. Disse depois aos que desesperavam que eles the tinham sido entregues pelo Senhor, por anunciação de um anjo, e exortou-os a aceitarem o páo que ele próprio comia; e assim chegaram à ilha de Malta; para ai foram todos arremessados ilesos e com o navio despedaçado.]

O comandante soltara o navio da costa oriental, obtendo a ajuda do Austro, por cujo sopro, num caminho de crescente alegria e com as asas abertas das velas,

1070 a popa sulcava as águas. Mas o que é que alguma vez os dolos dos ventos mantiveram em sossego? Logo a quietude do pélago foi quebrada pelos sopros do Euro ${ }^{88}$, e a paz fingida do mar cerúleo embranqueceu em inchadas ondas. Por todo o lado o mar se enfurece e, levantando a sua massa do abismo irado,

1075 nega uma rota segura ao navio em apuros, que, elevado até aos astros e daí precipitado, se une ao mar, seguidor da terra e do céu. A mão hábil para a navegação carece da ajuda de uma arte amiga, perdem o ânimo por causa do gélido pavor e, cegos sob o negro nevoeiro,

1080 vêem o naufrágio iminente e, nas profundezas cerradas, aparece a imagem da morte. Por imposição histórica, sou chamado a percorrer vastas sirtes e a seguir amarras mutiladas e fragmentos de leme, mas não tenho eu confiança

${ }^{88}$ Como é sabido, Austro e Euro são as designaçôes do vento sul e do vento leste, respectivamente. 
numa língua tão frágil para esses baixios e evitarei

tactear por muito tempo violentas procelas, para que uma onda mais violenta não esmague porventura a humilde palavra do cantor ${ }^{89}$. Importa tocar nalguns pontos. Tentarei areias seguras: as estrelas-guia esconderam-se do navio vagabundo, e o eixo do Sol não rompeu com seus raios pelas nuvens. E, embora o seu círculo tivesse já ritualmente completado muitos dias, 1090 aconteceu no pélago uma única noite e, nesse tempo, não se entregaram a comida alguma. Ai, como é grande o castigo do medo, para esquecer o suplício da fome! Com frequência, uma coisa má fornece as sementes para as boas causas. Os jovens marinheiros e a coorte de soldados teriam atentado, num oceano mais calmo, 1095 contra a dignidade de homem tâo ilustre, cuja vigilância é finalmente afrouxada, e os acossados por este mar selvagem começam a venerar o que reconheceram como seu porto. Aquela calamidade obriga a que náo se possa esconder o que Paulo era e a revelar o santo, tendo o mar por advogado; exilada a luz, trabalham os elementos para mostrar o herói, e, no meio das trevas, desponta a fé radiante. Nasce o loureiro para os justos do preço que o terror inflige, e cresce na adversidade a virtude persistente, que, usando por testemunhas os perigos, enfrenta as provações rumo ao mérito. Paulo, de pé, anima finalmente os coraçóes desesperados com estas palavras piedosas: "Oxalá tivesses desejado, juventude fiel, obedecer mais cedo aos nossos conselhos de não abandonar as praias de Creta, sujeita à fúria das profundezas enlouquecidas!

${ }^{89}$ O topos da modéstia do autor está bem patente nesta observação. Arátor parece seguir o seguinte preceito de Horácio: o escritor deve escolher matérias à altura das forças, tendo consciência da carga que os seus ombros podem suportar. Cf. Hor. A. P. 3840. 
1110 Não terias de suportar as ameaças do pélago e do céu, nem o triste fardo da perda devastadora, nem a vida, em desespero com semelhante tormenta, choraria a iminência da morte. No entanto, as alegrias que transcendem o desejo humano, é fácil a Deus concedê-las; para ele é mais digno ali o exercício

1115 da generosidade, pois já ninguém a espera. É que um anjo enviado do Céu anunciou-me ao chegar, com plácida voz: 'O governador do Olimpo confiou-te a multidão que este barco transporta, para que não se atire, naufragando, contra rochedo [algum.' Tomai isto por certo, e não serei enganado eu, merecedor

1120 das promessas de Deus, por uma esperança vá; surgirá uma ilha, a nós concedida como porto, em cujo ancoradouro nos será permitido usufruir da terra alcançada e verificar os graves danos do navio despedaçado, sem temer perigo algum.” A estas palavras desmorona-se a ira do mar e, há longo tempo subtraída,

1125 brilha a luz restaurada que, depois de aberto o véu da noite, pareceu estender um solo, oferecido aos nautas pela hospitaleira ilha de Malta, próxima da costa siciliana a remo.

Antes, porém, de vencerem a violenta agitação das águas, Paulo exclama: "Vós que estais cansados, libertai-vos dos jejuns, 1130 provai agora do pão, catorze dias passados", dizia ele, "tal como nós também o comemos!" Examinemos por que regra os mistérios da figura sagrada prevalecem memoráveis: quando brilharam as luzes do primeiro mês, no dia correspondente àquele número, foi ordenado à multidão que se alimentasse

1135 das carnes de um cordeiro ${ }^{90}$ e, ao tocar a sua protecção, ela mereceu escapar incólume às nilíacas trevas ${ }^{91}$. Partindo deste exemplo,

${ }^{90} \mathrm{Vd}$. Ex. 12.1-11.

91 Deus ordenou que todas as casas dos judeus fossem assinaladas com o sangue do cordeiro para não ferir de morte os seus 
num intervalo de tempo similar, Paulo persuade os que deseja arrebatar do abismo do mundo a comer consigo e a provar o alimento sagrado, seguindo os passos dados por Moisés. Para quem observa o feito de ambos,

as duas acçôes são diversas nos lugares, mas similares nas causas ${ }^{92}$ e a salvaçâo repetida é tirada de uma única fonte:

Cristo é o cordeiro; também se considera ser Cristo o pão do Céu, ensinamento que ele mesmo dán ${ }^{93}$; quem tiver tomado Jesus no seu corpo abstém-se do inimigo, e não mais o Faraó e o Egipto conservam seus poderes. De imediato, todas as armas do Demónio se afundam nessas águas, das quais renasce como criança aquele que era cativo. É também abandonada a agitação do salgado abismo, superados os pântanos do hediondo dragáo, e Cristo, já verdadeiro pastor para quem busca alimento, concede 1150 pastagens ao rebanho resgatado, chamado nos seus próprios nomes ${ }^{94}$. Neste exemplo, também a lua dourada contém a figura da Igreja: aquela, a partir do décimo quarto dia do primeiro nascimento da luz, avista-se já cheia, porque, a partir do corpo de Jesus, foi aumentando o seu círculo e irradiando uma luz perene.

primogénitos, atingindo apenas os egípcios. Cf. Ex. 12.12-13.

92 "Similares nas causas", porque ambas envolviam a passagem do mar. No caso de Moisés, a passagem do mar Vermelho salvou Israel da perseguiçáo egípcia. Por seu turno, a miraculosa acalmia da tempestade por Paulo salvou a tripulação do naufrágio iminente.

${ }^{93} \mathrm{Vd}$. Jo. 6.35: "Eu sou o pão da vida".

${ }^{94}$ Cf. Jo. 10.3: "A este o porteiro abre, e as ovelhas ouvem a sua voz; e chama pelo nome as suas ovelhas, e leva-as para fora". 


\section{[Secçáo XVIII]}

[Passo em que, na ilha de Malta, quando S. Paulo juntava vides para a fogueira, uma vibora se the agarrou à mão; aquele a quem os bárbaros consideravam homicida e julgavam moribundo atirou a vibora para a fogueira; os que tinham pensado que morreria mal aparecesse o tumor de tal forma se maravilharam por estar ileso que o chamavam Deus.]

Para repelir o frio que crescia das chuvas, Paulo juntara sarmentos para a fogueira. Eis que uma vibora, envergando as armas do Demónio e indo ao encontro das chamas ascendentes, se lhe cravou na mão com a antiga ferocidade e, junto ao fogo, lhe causou [uma ferida

1160 com seu gélido veneno. Porque desejas ainda, malvada e criminosa serpente, desviar [os homens] para longe do Senhor e, na [novidade da lei, preparas velhas rapinas? Por que razão, ó amante da morte, de quem tu és a própria mãe, renovas teus combates contra os redimidos? Vens como predadora, mas ficas aí como presa e, ministrando daí

1165 a morte, és destruída, ó enganadora, pelos ramos de outra árvore, e, após a cruz de Cristo, uma porçáo de lenho significa para ti a morte ${ }^{95}$. Não muito longe dali, possuidores de um coração agreste, estavam os filhos de um povo bárbaro, que, num terrível murmúrio, vociferaram em uníssono: "Este aqui é sem dúvida culpado

95 Desde o início da secção (v. 1156), Arátor estabelece o paralelo entre a serpente genesíaca que enganou Eva e a serpente que atentou, em Malta, contra a vida do Apóstolo. O poeta assinala, porém, uma diferença fundamental: enquanto a primeira serpente, usando como pretexto a árvore $(G n .3 .1-5)$, saiu vencedora e trouxe consigo a morte espiritual, agora a mesma serpente é duplamente destruída pelos "ramos de uma outra árvore", a saber, pelas vides com que Paulo a queimou no fogo e pelo lenho da cruz de Cristo. 
de um crime de sangue, já não está seguro em margens algumas, contra ele se enfurecem o mar e a terra." Discutem assuntos humanos e comprovam factos divinos. Com efeito, a besta suspensa no dedo, arremessada para o fogo, ali se agita; é, com justiça, devolvida às chamas que ela própria tinha antes ateado, ao desencadear o fogo do pecado a partir do qual se inflama a Geena. Aquecido, o gelo do seu veneno derrete-se em cinzas, e a soberba da gélida pestilência perece no calor; esse fogo e os lestos fumos ganham inusitadas forças e levam consigo o seu ressequido alimento. Mas tu, ó fé, fazes agora cozer a serpente, usando o teu fogo; a ti se submete o frio inimigo e, ao acender sucessivas fogueiras, ele mesmo arde no seu viperino gelo fumegante. Diziam que [Paulo] sucumbiria mal chegasse o tumor. Quanto discorre pela vacuidade a mente desconhecedora do bem! Já do corpo de Paulo se ausentara o veneno, desde o momento em que dele saiu o terror escamoso que a antiga serpente lhe incutia ${ }^{96}$; purificado no rio etéreo e amarrando o seu corpo à cruz de Cristo, não pode a serpente matá-lo; devora o veneno essa chama ajo poder buscou nas águas sagradas; queimado por elas, vai fumegando quem se lamenta que os velhos colonos regressem à sua pátria. Maravilhados por assim se manter tanto tempo ileso, dizem os jovens que ele é um deus. Aprende, por fim, rude indígena, com que poder reina nos Céus quem concede maravilhas tamanhas ao ponto de julgares serem isso os seus servos! Urge agora melhor elucidar o motivo da figura presente no dom do notável feito: a serpente, origem da morte - pois a morte nascida da mordedura

${ }^{96}$ Aquando da sua conversão a caminho de Damasco, Paulo perdeu a visão (Act. 9.8), que só recuperaria após a bênção de Ananias, quando lhe caíram dos olhos uma espécie de escamas (Act. 9.18), recebendo logo depois o baptismo. 
do pecador tira daí o seu nome ${ }^{97}$ - e adversária dos justos, deseja travar a sua mão, porque a máo provedora do conveniente é justamente chamada 'obra' ${ }^{98}$; quem divisar tal inimigo

1200 sacuda-o vigorosamente e queime-o no fogo do Senhor. Paulo, mal se apercebeu dos ardis de um perigo iminente a querer arrastar-se para ele, agarrando nos dardos celestes, empurrou os dolos para o fogo, de cujas achas foi acesa a incipiente fé, depois de acrescentar o brilho àquelas mentes,

1205 e da copiosa fonte avançou depois este calor para os povos.

\section{[Secção XIX]}

[Passo em que S. Paulo, passando os três meses de Inverno na ilha de Malta, depois de ter curado o pai de Públio, o homem mais proeminente daquela regiäo e que já tinha perdido a esperança, e vários outros doentes, chegou finalmente a Roma, navegando com o sopro do Austro e deixando para trás muitos lugares do mar e da terra.]

Durante os três meses de Inverno, na regiáo de Malta, Paulo oferece inefável auxílio e alivia da morte iminente o pai de Públio; à vista de um tal benefício, acorrendo de todos os lados, muitos agarraram a inesperada cura.

${ }^{97}$ Fazer derivar mors de morsus tem sentido bíblico mas não etimológico. Até Aires Barbosa, que geralmente está de acordo com as observaçóes do poeta, náo deixa de contestar vivamente tal etimologia (Barbosa 1516 cxlv e cxlv vo). Não obstante, esta derivação etimológica é registada por Sto. Isidoro de Sevilha (Etimologias 11.2.31), mas, mesmo aí, ela aparece entre parênteses nas ediçôes que consultámos: Mors dicta, quod sit amara, uel a Marte, qui est effector mortium (siue mors a morsu hominis primi, quod uetitae arboris pomum mordens mortem incurrit).

${ }^{98} \mathrm{Ou}$ seja, ao atacar a mão de Paulo com o intuito de lhe causar a morte, a serpente pretendia impedir a "obra" da pregaçáo do Apóstolo. 
Brota, entretanto, a frondosa folhagem da resplandecente Primavera, rejuvenescendo a terra com a partida da velha era do gelo, e o Austro, elevando o barco de velas condescendentes, ofereceu aladas ondas num plácido mar. Convém que sopre este, celebrado na voz do profeta, que canta no Austro a formosura abrasadora da fé $e^{99}$. Assim também, depois de vencidas para nosso gáudio as procelas, percorrendo cada uma das muitas cidades de bairros diversos, chegou ele aos sublimes pináculos da excelsa Roma ${ }^{100}$. $\mathrm{O}$ relato me obriga a dizer mais longamente porque chegaram ao mesmo tempo as duas luzes do mundo e, dentre tantos sítios, escolheram um único lugar, através do qual uniriam as suas estrelas os que serenam todos os campos com as virtudes da fé. Embora o motivo de tal facto se possa estender por inúmeras figuras, eu de bom grado anunciarei algumas com a protecção dos mesmos. Pedro surgiu para ser o príncipe no corpo da Igreja; esta [cidade] torreada circundou-lhe a cabeça com as regióes do mundo; para si converge o que é grande, para todos os lugares contemplarem os seguros pináculos da rainha das terras. Aí presente com toda a justiça, Paulo, eleito como eterno mestre dos gentios, solta as rédeas da palavra para esta [cidade], que, tendo sido a escolhida, ensina os povos; tudo quanto aí proclame, a glória da cidade obriga o mundo subjugado a ouvi-lo. E é matéria digna da coroa de Pedro e de Paulo superar as ameaças de César, revelar as leis do Céu na cidadela do tirano e vencer na contenda o mais alto tribunal, não fosse um inimigo insignificante arrecadar os louros.

${ }^{99}$ Cf. Sl. 126.4: "Faz voltar, Senhor, os nossos exilados, como as torrentes do Austro".

${ }^{100}$ É aqui que termina a glosa dos Actos dos apóstolos. Os últimos trinta e um versos da História apostólica são um acrescento ao relato de Lucas. 
O Egipto sustenta a imagem do mundo: o povo merecedor de ser daí chamado foi entregue a dois comandantes, cuja missão foi unida pelos laços fraternais do nascimento ${ }^{101}$.

1240 Inúmeros ídolos, que em Roma tinham sido acumulados do mundo submetido, esmagavam os coraçôes sujeitos às trevas. E esse povo livre, a quem antes o Faraó acorrentara, saiu, com o mesmo número de guias, das sombras do Egipto e, pelo baptismo de Deus, representado na altura pela imagem do mar,

1245 descobriu o celeste alimento, ao encontrar o caminho da vida. Também aqueles estavam irmanados pelo amor, para cuja amplidáo os actos se sobrepuseram à natureza; estes gémeos, apresentou-os [aos Céus não o mesmo mas um dia igual, e, estando volvido o tempo de um ano, a paixão consagrou o dia repetido ${ }^{102}$,

1250 e a graça desta aliança obtém a eterna palma.

101 Trata-se, evidentemente, de Moisés e Aarão, a quem Deus confiou a libertação do cativeiro do Egipto (cf. Ex. 4 e 5). O cotejo entre Moisés e Aaráo, irmáos de sangue, e Pedro e Paulo, irmãos pelo martírio, tem um alcance que vai além da libertação dos povos, aqui referida por Arátor. Na verdade, se Moisés e Pedro se assumiram como os primeiros chefes de dois povos, o israelita e o cristáo, Aarão e Paulo destacaram-se pela sua eloquência, imprescindível em ambos os casos.

${ }^{102}$ Numa solenidade que remonta ao século III ou IV, a Igreja celebra os dois santos no dia 29 de Junho, data presumível do seu martírio. $\mathrm{O}$ poeta segue a tradição que afirmava terem sido ambos martirizados no mesmo dia, volvido exactamente um ano. A atestar estas afirmaçóes de Arátor, Prudêncio, no poema Passio apostolorum Petri et Pauli (hino 12 do Peristephanon), depois de relatar o crucifixão de Pedro (vv. 11-20), narra o martírio de Paulo às máos de Nero, dizendo: "Quando a órbita perfeita do círculo solar percorreu o trajecto de um ano completo / e o Sol, nascido de novo, trouxe o mesmo dia, / Nero lançou a sua raiva ardente contra o pescoço de Paulo: / ordena que seja sacrificado o mestre dos gentios" (vv. 21-24, tradução nossa). 
Epístola de Arátor a Parténio 
(Página deixada propositadamente em branco) 
Ao ilustre senhor, o magnificentíssimo e excelso Parténio, Mestre de Ofícios e patrício ${ }^{1}$, o subdiácono Arátor.

Se, ó grandioso, te quiser lembrar as honras de teus pais, dificilmente uma página, preenchida até ao verso, me daria

[espaço.

Grande desde teus avós e antepassados, tu ultrapassas a linhagem pela conduta, e a tua origem se inclina perante os teus méritos, excelente Parténio, cujo nome, ó casto, posto desde a eternidade

${ }^{1}$ A identidade do destinatário e a autoria da própria carta não são pacíficas. $\mathrm{Na}$ verdade, se as cartas a Floriano e a Vigílio são registadas por todos os códices manuscritos, já a dirigida a Parténio apenas se encontra em dois (Paris., B. N., lat. 2773; e Paris., B. N., lat. 9347), que a transcrevem sem qualquer comentário ou glosa, e não se encontra em nenhuma das ediçôes impressas no século XVI, como é o caso da edição aldina de 1502 (a primeira edição impressa da obra). Arátor refere-se ao amigo como magistro officiorum atque patricio, o que deixa entender que Parténio era um homem da alta sociedade, desempenhando importantes funçôes na corte. $\mathrm{O}$ cargo de magister officiorum foi instituído por Constantino, em 320 , e continuaria a vigorar quer no Império Bizantino quer na Itália ostrogoda, após a queda do Império Romano. Nomes táo importantes como Boécio ou Cassiodoro contam-se entre os dignatários que desempenharam tal funçấo ao serviço de Teodorico, $o$ Grande. Finalmente, juntando o nome dos destinatários das três missivas, parece haver da parte de Arátor um claro desejo de fazer conhecer e difundir o mais amplamente possível a sua obra: um monge, Floriano; um membro do clero romano, nada menos que o próprio papa Vigílio; e, finalmente, um laico com grande influência na sociedade e nos meios literários, como demonstra esta carta. 
e motivo de orgulho, é mais uma honra do teu espírito. A língua, qual arauto, assinalou a castidade vindoura, e o nome por que te chamam patenteia a glória de ambos ${ }^{2}$. Possuis cinturóes vários, mas tu torna-los grandiosos,

pois cada honra que te é dada depressa cresce em si mesma. Quem poderá cantar graças tamanhas? Serei breve: sozinho, reúnes tudo quanto faz separadamente um homem grande. Tu, ó eloquente, entre as multidóes do Ródano e do Reno [és retumbante;

a corte régia como homem dulcíssono te aprecia. Esplêndida em tantos domínios, olha-te como erudito e felicita-te com paternal amor a Germânia, para quem, a partir de tal filho, brilha a maior das glórias, igual à que é dada no fórum de Rómulo pela espessa toga. Eu mesmo te vi, te vi ainda jovem num discurso eloquente a ombrear com os antigos nobres de Itália; tendo aí cumprido ofício de embaixador, foste como orador enviado para solicitar a riqueza da liberdade. Adocicaste os ouvidos dos Getas com palavras propícias, e as públicas promessas auxiliaram tua pátria.

25 O insigne rei, em cujas mãos se encontrava a resolução do caso, como ouvinte exultante, nada te pôde negar ${ }^{3}$.

${ }^{2}$ Tal como fizera na carta a Floriano, também aqui Arátor se serve do argumento cratílico para enaltecer Parténio. São quatro versos (vv. 5-8) a assinalar a relaçáo entre Parténio e o vocábulo grego parthenía, "castidade", apontando para a teoria platónica da providencialidade dos nomes.

${ }^{3}$ Do verso 13 ao 26, Arátor elogia a eloquência e o poder de persuasão do amigo, manifestados em diversas ocasióes e lugares. A verdade é que, lendo os diversos autores que opinaram sobre a questão, a identificação de Parténio é controversa. Arátor conheceu-o, enquanto estudante, em Ravena (cf. v. 36: his quoniam Laribus tenebramur in urbe Rauennae), mas, ao não mencionar a 
Quando a fama voando, numa corrida ligeira, começou [a espalhar tais feitos e levantou a cabeça com ouvido atento, a fluidez da tua sólida eloquência mostrou-se aos povos e a multidão ansiosa escoltava teus passos; e de tal modo que cada vez que abrias rios pelo movimento [dos lábios

ela corria como se fosse saciar uma sede estival. $\mathrm{Eu}$, desejoso de me banhar nas riquezas da língua, na qual vais fluindo, ó inestimável, como a onda do Tejo, estava a teu lado como hóspede boquiaberto, noite e dia,

pois, na cidade de Ravena, estávamos retidos nessas casas. Que livros, que nomes tu me davas a conhecer, ó sábio! Ao mesmo tempo, repetindo tanta coisa, eras a imagem [de um livro!

Aí, sob a tua vigilância, li pela vez primeira as Histórias de César, que ele mesmo compôs para si como diários ${ }^{4}$.

Recitavas com plácido e doce encanto os poetas

que tiveram falaciosa arte e arrogante brilho.

No entanto, ó grandioso, aconselhavas os verdadeiros vates, cuja fé puxou os metros para as suas leis,

vida comum em Miláo, parece claro não ser este o sobrinho de Enódio, Parténio, com quem privou em criança. Alguns dizem que se trata do neto de Avito, imperador romano entre 455 e 456, mas parece-nos mais avisado a identificação de Parténio como o neto de Rurício, bispo de Limoges de 485 a 510. Este Parténio casou-se com Papianilha, neta de Avito, e, depois da ocupaçáo ostrogoda da Provença, em 508, foi enviado como emissário à corte de Teodorico, em Ravena. É certamente a essa embaixada que Arátor se refere nestes versos. Em 544, quando Arátor lhe envia esta missiva, ele aparece já como magister officiorum ao serviço dos reis francos. Cf. Mathisen 1999 204, e Green 2006 254-255.

4 Trata-se, obviamente, dos Commentarii de bello Gallico. 
tais como Ambrósio, ao engrandecer-se nos hinos do Hibla, que tu, abelha, lhe anunciaste ainda deitado no berço; tais como Decêncio, que foi manancial dessa mesma arte, e como tu, lira sidoniana, que cantas entre os Arvernos 5 . Em tempos, nos meus anos de juventude, tive eu um desejo:

espalhar com meus versos um eterno canto lírico e até reescrever as partes que a lenda inventou,

e ser arrastado pela futilidade através de um mar vazio. Quando a nossa frágil avena te entoou esses cantos, pois no teu amor, amigo meu, sempre encontrei amparo, disseste: "Oxalá escolhesses desviar com maior rectidão o curso dessa voz para o louvor do Senhor, de tal modo que não te seja a ti ocultada a terra, mas oferecida, pois teu nome é Arátor, por ele te chamamos nós!”6 Resolvi, confesso, que, se porventura um dia merecesse seguir os frutos do meu talento para melhores fins, a obra que eu cantasse seria levada para qualquer lugar

${ }^{5}$ Foi, portanto, o amigo que aconselhou a Arátor a lira cristã, aqui representada por Ambrósio, Dracôncio e Sidónio Apolinário. Acerca do primeiro, é referida a conhecida lenda das abelhas, que the inspiraram a eloquência e a doçura dos seus Hinos; o segundo é o incógnito Decentius, que a maioria identifica como Dracôncio, poeta dos finais do séc. V e autor do poema épico De laudibus Dei; para o terceiro, a referência aos Arvernos facilita a sua identificação como Sidónio Apolinário (ca. 430-ca. 486), poeta, alto funcionário do Império Romano e bispo de Arverni (Clermont-Ferrand). Nos versos 39 a 48, Arátor confessa ter adquirido junto de Parténio uma tripla cultura: a historiografia clássica, representada por César; a poesia pagã, encantadora mas falaciosa (vv. 41-42); e a cristâ, a dos "verdadeiros vates" (v. 43), aos quais dedica compreensivelmente mais versos.

${ }^{6}$ Como é sabido, arator significa "lavrador". Parténio aconselha, pois, o amigo "Lavrador" a escolher terras mais propícias para o seu arado: as do louvor a Deus. 
onde tu por acaso estivesses, ó melhor dos homens. Agora, o dia prometido instiga-me o desejo de finalmente dar cumprimento à minha dívida e aos meus acordos, [ó sábio. Recebe o poema que extraímos do resplandecente mar, e aceita com reconhecimento as águas, ainda que exíguas. ${ }^{7}$ Nessa superfície permanece um profundo oceano de matérias, donde, a custo, uma breve gota com a boca sorvemos. O facto é que eu, unido à graciosa balaustrada da Igreja Romana e transformado em ovelha de cabeça rapada, olhando os ricos pastos e os volumes soalheiros de Cristo, procurava saborear tudo no meu paladar, e num momento devorar as odes, acostumado às flores davídicas, mas num outro a mente voraz o Génesis desejava. $\mathrm{E}$, querendo ao mesmo tempo colher violetas e lírios, que o velho e o novo perfume reduplicaram, ocorreu-me aquele a que o cânone chama Actos, o livro repleto da ceifa apostólica no mundo, onde o Senhor nos libertou, sendo Pedro seu pescador,

das entranhas do salgado e cerúleo mar e, na imagem desvendada, um navio concedeu para a fome saciar aos povos nele embarcados. Embora aprendiz, a partir da história daquele ${ }^{8}$, compus [o poema

e zeloso entreguei as palavras ao meu pastor, que em maior abundância traz ao cantor novas palavras

[com o seu auxílio, sem o qual ninguém pode dizer nada digno acerca dele;

${ }^{7}$ Cf. Arator Ad Flor. 7-8.

8 "Daquele», isto é, de Pedro, a quem Arátor consagra todo o primeiro livro da História apostólica. 
tais versos foram mostrados ao egrégio pai, o papa, e os escrínios secretos da Igreja guardam-nos devidamente. Vamos, então! Que o teu contributo honre os livros recebidos.

A causa divina dará o valor do meu salário, porque, na religião do Mestre, há vários pontífices,

tantos homens bons fornece a zelosa Gália;

aí vive Firmino, aquele sacerdote venerável ${ }^{9}$, que pode alimentar o povo com a palavra da doutrina.

O seu louvor estende-se até às fronteiras de Itália e a sua glória tem nome para lá da pátria.

Liçóes que agradaram ao detentor da sede apostólica,

ninguém duvida de que serão aprazíveis aos virtuosos! E jamais penses que te há-de faltar a recompensa da fama, estas palavras encimam a obra que aí farás editar ${ }^{10}$. Juntos iremos os dois aonde chegar esta página, e sempre a glória de Parténio andará em toda a boca.

${ }^{9}$ Trata-se de S. Firmino, bispo de Uzès de 538 a 553.

${ }^{10}$ Como nota Châtillon, este verso é praticamente ininteligível, e podemos mesmo imaginar uma lacuna onde se explicitariam as condiçóes de edição do poema. De qualquer maneira, há aqui uma referência clara ao pragmatismo desta missiva: a Parténio é confiado o encargo de editar a História apostólica além dos Alpes, na Gália ou talvez na Burgúndia, o lugar provável onde o amigo se encontraria, como nos leva a crer o verso 13: Tu, facunde, sonas Rhodani Rhenique cateruis. Cf. Châtillon 1963 55-57. 


\section{BibLIOGRAFIA}

Adler, Ada, ed. (1933), Suidae Lexicon. Pars III. Leipzig, Teubner.

Barbosa, Aires (1516), Aratoris cardinalis "Historia apostolica" cum commentariis Arii Barbosae Lusitani. Salmanticae, in aedibus Ioannis de Porris.

BIBLIA SACRA, iuxta Vulgatam Clementinam (1999). Noua editio [...] ornata a Alberto Colunga et Laurentio Turrado, Matriti, Biblioteca de Autores Cristianos.

Bíblia SAGRADA (1984). Lisboa, Difusora Bíblica (Missionários Capuchinhos).

Blomgren, Sven (1974), "Ad Aratorem et Fortunatum adnotationes", Eranos 72 143-155.

Bornecque, Henri (2003), Ovide. Les amours. Ed. et trad. Paris, Les Belles Lettres.

Châtillon, François (1963), "Arator déclamateur antijuif", Révue du Moyen Âge Latin 19 70-128.

Cunningham, M. P., ed. (1966), Prudentius. Liber peristephanon, CCSL 126 251-389.

Curtius, Ernst R. (1996), Literatura européia da Idade Média latina. Trad. de Teodoro Cabral e Paulo Rónai. São Paulo, Ed. Hucitec.

Deproost, Paul-Augustin (1990), L'apôtre Pierre dans 
une épopée du VIe siècle. L"Historia apostolica" d'Arator. Paris, Institut d'Études Augustiniennes.

DucKett, Eleanor S. (1961), In the gateway to the middle ages: France and Britain. Michingan, University of Michigan Press.

Fernandes, R. M. Rosado (1984), Horácio. Arte poética. Introd., trad. e comentário. Lisboa, Editorial Inquérito.

Fontaine, Jacques (1981), Naissance de la poésie dans l'occident chrétien. Esquisse d'une histoire de la poésie chrétienne du III au VI siècle. Paris, Institut d'Études Augustiniennes.

Forster, Edward S. (1984), Florus. Epitome of roman history. Transl. Cambridge, Harvard University Press.

Fridh, Å. J. - Halporn, J. W., eds. (1973), Cassiodorus. Variarum libri XII, CCSL 96 3-499.

Green, Roger P. H. (2006), Latin epics of the New Testament: Juvencus, Sedulius, Arator. Oxford, Oxford University Press.

Hartel, W., ed. (1882), Ennodius. Dictiones XXVII, CSEL 6 430-506.

Hartel, W., ed. (1882), Ennodius. Epistulae, CSEL 6 $1-260$.

Hillier, Richard (1993), Arator On the Acts of the apostles: a baptismal commentary. Oxford, Clarendon Press. 
Laistner, M. L. W. - HURST, D., eds. (1983), Beda Venerabilis. Expositio Actuum apostolorum, CCSL 121 3-99.

Manso, José Henrique (2011), Comentário de Aires Barbosa ao segundo livro da História apostolica de Arátor. Lisboa, Fundação Calouste Gulbenkian / Fundação para a Ciência e Tecnologia.

Martin, J. (2002), Aratos. Phénomènes. Ed. et trad. Paris, Les Belles Lettres.

Mathisen, Ralph W. (1999), Ruricius of Limoges and friends. A collection of letters from visigothic Gaul. Liverpool, Liverpool University Press.

Mckinlay, Arthur Patch (1942), Arator. The codices. Cambridge (Massachusetts), The Mediaeval Academy of America.

Mckinlay, Arthur Patch, ed. (1951), Aratoris subdiaconi De Actibus apostolorum, CSEL 71.

Medeiros, Walter de Sousa (1953), Aires Barbosa escorço biobibliográfico seguido do texto e versão da "Antimoria". Tese de licenciatura apresentada à Faculdade de Letras da Universidade de Lisboa.

Moricca, Umberto (1932), "Aratore" in Umberto Moricca, Storia della letteratura latina cristiana. Vol. 3, Parte 1. Torino, Società Editrice Internazionale 209-215. 
Orbán, A. P., ed. (2006), Aratoris subdiaconi Historia apostolica, CCSL 130-130A.

Oroz Reta, J. - Marcos Casquero, M. - Diaz y Diaz, M. (1994), Etimologías de San Isidoro de Sevilla. Ed., trad. y notas. Madrid, Biblioteca de Autores Cristianos.

Perret, J. (2002), Virgile. Énéide. Vol. 2 (livres 5-8). Ed. et trad. Paris, Les Belles Lettres.

Rackнam, H. (1942), Pliny. Natural History. Vol.

2 (books 3-7). Transl. Cambridge, Harvard University Press.

Riché, Pierre (1995), Éducation et culture dans l'occident barbare: VI'-VIII siècle. Paris, Seuil.

Schilling, R. (2003), Ovide. Les fastes. Vol. 1 (livres 1-3). Ed. et trad. Paris, Les Belles Lettres.

Schrader, Richard J. (1977), "Arator: revaluation", Classical Folia 31 64-77.

Thraede, K. (1961), “Arator”, Jahrbuch für antique \& Cristentum 4 187-196.

Villeneuve, François - Ricoux, Odile (1997), Horace. Odes. Introd., trad et notes. Paris, Les Belles Letttres. 


\section{ÍNDICE ONOMÁSTICO*}

AbraÃo: $H A$ 283, 292

Actos (dos apÓstolos): Ad Vig. 19; Ad PART. 78

ADÃO: $H A$ 376, 438, 969

Ambrósio: $A D$ PART. 45

Antíoco: $H A 40$

Apóstolo (Paulo): HA 437, 744

ÁQuila: $H A$ 510, 529

ArÁtor: AD PART. 58

Arvernos: AD PART. 48

ÁsIA: $H A 311,1039$

Atenas: $H A$ 443, 488

Augusto: HA 1057

Austro: $H A$ 1068, 1212, 1215

Averno: $H A$ 123, 612, 790

Boa Nova: HA 253

CÂNTICO (DOS CÂNTICOS): AD VIG. 26

CÉcrope: HA 455

CÉsar: HA 1055, 1056, 1234; AD PART. 39

Cesareia: HA 1030

CÉu(s): HA 105, 161, 163, 481, 788, 873, 1116, 1144, 1193, 1234, 1247; AD FLOR 4

CHipre: HA 5

Cordeiro (Cristo): HA 75, 196, 602

Corinto: $H A 508$

CRETA: HA 1109

Criador (Deus): HA 24, 66, 72, 93, 219, 377, 637, 840, 930; AD Flor 11 Cristo: HA 71, 87, 98, 104, 209, 233, 249, 271, 303, 329, 381, 475, 502, 516, 520, 588, 600, 646, 685, 738, 786, 811, 831, 851, 879, 896, 912, 928, 938, 1047, 1143, 1150, 1166, 1187; AD PART. 71

DAVID: $H A 70,221,676$

DeCÊNCIO: AD PART. 47

DemÉtrio: $H A$ 688, 725, 747

Demónio: HA 648, 1146, 1158

* Neste índice, remetemos para os números dos versos do segundo livro da História apostólica $(H A)$ e das cartas que acompanham o poema (Ad Flor., Ad Vig. e Ad Part.). Excluímos desta lista as referências nos tituli das cartas e das diversas secçóes da História apostólica. 
Deus: $H A 44,72,99,117,130,146,167,186,195,214,232,246,262$, $283,288,300,350,386,478,499,592,596,651,664,757,767$, 772, 832, 901, 906, 937, 1114, 1120, 1244

Dia do Juízo: $H A 475$

DiANA: $H A$ 690, 693, 705, 712, 715

Dionísio (Areopagita): HA 482

ÉfESO: $H A$ 570, 624, 688

Egipto: $H A$ 43, 1145, 1237, 1243

Epístola (de S. Paulo): HA 83 (1 Cor.), 821 (EF.), 919 (2 Tim.)

ESCRITURA(s): HA 136, 594, 619, 731

Espírito (Santo): HA 1, 305, 310, 546, 571, 575, 579, 618, 827, 900, 908 ESTÊVÃO: HA 965

Euro: $H A 1242$

Êtico: $H A 761,815$

Eva: $H A 433$

EXODO: HA 340

FARAÓ: $H A$ 1145, 1242

FÉLIx: $H A 1048$

FEsto: HA 1050, 1056

Filho (Deus): HA 900, 907

FiLIPOS: HA 384

Firmino: $A D$ PART. 93

FLORIANO: AD FLOR 1

GÁlIA: $A D$ PART. 92

GEENA: $H A 1175$

GÉNESIS: AD PART. 74

Germânia: $A D$ PART. 16

GeTAS: $A D$ PART. 23

Hibla: $A D$ PART. 45

Histórias (COMENTÁRIos sobre a GUERRA DAS GÁLIAS): Ad PART. 39

IgreJa: $H A$ 19, 131, 150, 201, 291, 358, 410, 613, 686, 804, 850, 890, 1152, 1225; AD VIG. 9; AD PART. 69, 88

ILÍRIA: $H A 315$

INFERNO: $H A 817$

ITÁLIA: $A D$ PART. 20, 95

JAСОВ: $H A 485$

Jeremias: $A D$ VIG. 26

JERUSALÉM: $H A 827$

Jesus: $H A$ 90, 228, 325, 597, 643, 950, 1063, 1145, 1154

JoÃo (ВартіSTA): $H A$ 78, 573, 584, 598, 602

Jов: $A D$ VIG. 26 
JudEIA: $H A$ 133, 659, 909, 958, 1005

JuDEUS: $H A 834$

LÁCIO: HA 1052

Lei (Pentateuco): HA 85, 208, 304, 515, 675, 742, 893, 926, 1037

LICAÓNIA: HA 156

LísIAS: $H A 1018$

Listra: $H A 157$

LuCAS: HA 328; AD VIG. 19

MaCedónia: HA 318, 384

MaLTA: $H A$ 1127, 1206

Mar Vermelho: HA 85

MARIA: HA 70, 299

Mediador (CRISTO): HA 301

Mestre (Cristo): HA 4, 238, 331; Ad PART. 91

Mísia: $H A 311$

MoIsÉs: $H A$ 86, 733, 1008, 1140

NoÉ: $H A$ 803, 810, 813

Olimpo: HA 289, 1117

Omnipotente (Deus): HA 322

PAFO: $H A$ 6, 10

Pai (Deus): $H A 788,900,907$

Parténio: $A$ D Part. 5, 102

PÁSCOA: HA 962

Paulo: $H A$ 10, 29, 32, 35, 40, 82, 96, 135, 157, 160, 165, 174, 209,

217, 242, 256, 307, 368, 385, 390, 404, 425, 429, 443, 447, 485, 493, 506, 512, 516, 525, 551, 558, 567, 570, 600, 623, 630, 643, 646, 697, 772, 784, 799, 818, 826, 913, 919, 957, 975, 977, 993, 1000, 1018, 1022, 1030, 1032, 1050, 1052, 1054, 1058, 1099, 1105, 1129, 1137, 1156, 1182, 1184, 1201, 1207, 1229, 1223

Pedro: HA 3, 206, 217, 259, 565, 1225, 1233; AD VIG. 11; AD PART. 79

Penates: $H A 700$

Pilatos: HA 101

Píton: HA 385

Ponto: HA 510

Precursor (JoÃo Baptista): HA 596

Primavera: HA 1210

Profetas (livros dos): HA 208

PÚblio: HA 1208

Ravena: AD PART. 36

REBECA: HA 143, 291

Reino do Senhor: HA 128 
Reno: Ad PART. 13

RÓDANO: $A D$ PART. 13

RoMA: $H A$ 1062, 1218, 1240

Rómulo: AD PART. 18

SAGRADAS EsCRITURAS: HA 522

Salamina: $H A 5$

SALMO(S): HA 208, 676, 733; AD VIG. 24

SALOMÃO: HA 914

SAULO: HA 2, 937, 951

SenHor (Deus): HA 111, 126, 221, 470, 586, 591, 654, 741, 821, 853, 866, 1161, 1200; AD PART. 56, 79

SILAS: HA 405

Soberano (Deus): AD FloR. 15

Sol (Deus): HA 542, 936

TÁrtARO(s): $H A$ 481, 795, 815

Tejo: Ad PART. 34

TONANTE: HA 145

TRINDADE: HA 615, 824

TróıA: HA 753

VIgílio: $A D$ VIG. 3

VINGADOR (CRISTO): HA 479

VIrgem (Maria): HA 194 


\section{Volumes publicados na Colecçấo Autores Gregos e LATINos - SÉrIE TeXtos Latinos}

1. Márcio Meirelles Gouvêa Júnior: Gaio Valério Flaco. Cantos Argonáuticos. Tradução do latim, introdução e notas (Coimbra, CECH, 2010).

2. José Henrique Manso: Arátor. História Apostólica - a gesta de S. Paulo. Tradução do latim, introdução e notas (Coimbra, CECH, 2010). 
(Página deixada propositadamente em branco) 
(Página deixada propositadamente em branco) 
OBRA PUBLICADA

COM A COORDENAÇÃO

CIENTÍFICA

○

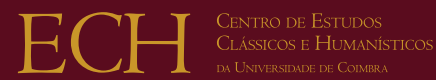

- $\mathrm{U}$

C - 